BNL 51301
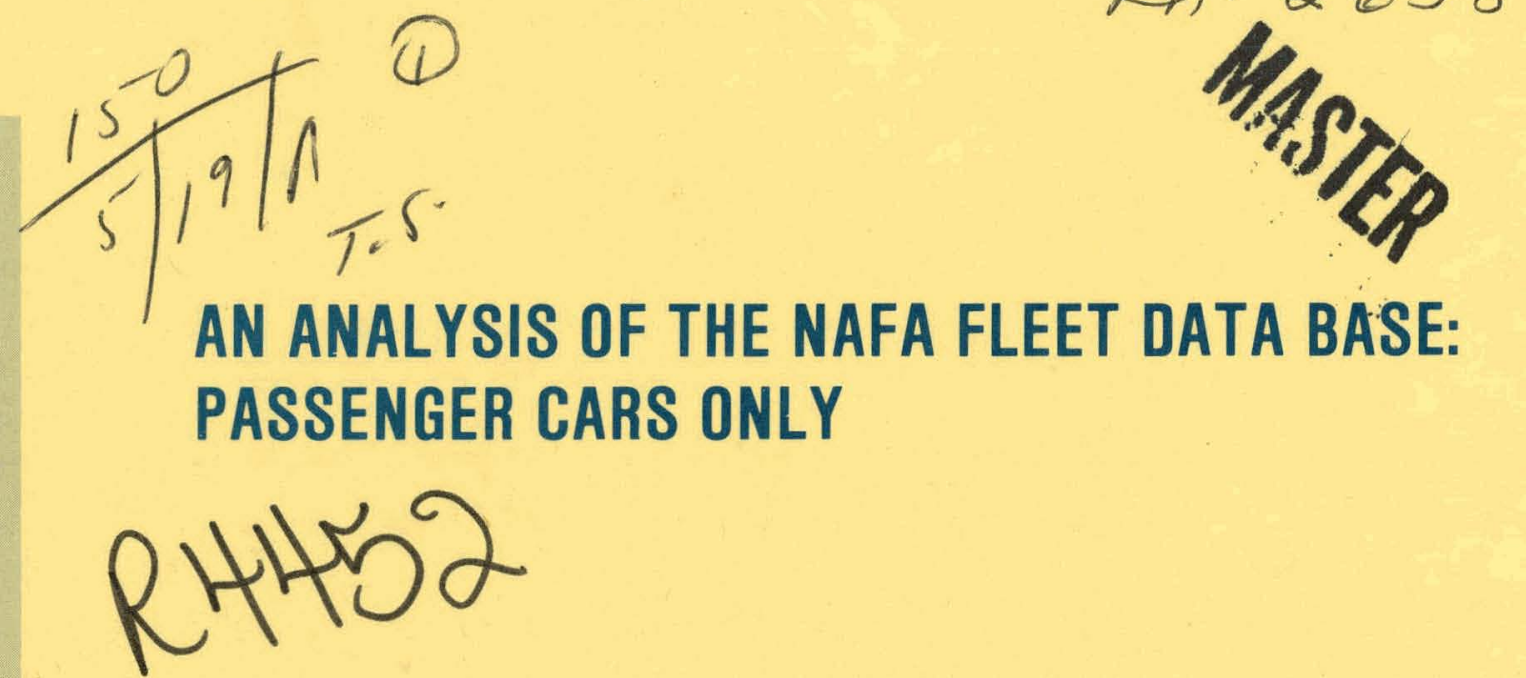

Deborah Shonka

September 1980

DEPARTMENT OF ENERGY AND ENVIRONMENT

BROOKHAVEN NATIONAL LABORATORY UPTON, NEW YORK 11973 


\section{DISCLAIMER}

This report was prepared as an account of work sponsored by an agency of the United States Government. Neither the United States Government nor any agency Thereof, nor any of their employees, makes any warranty, express or implied, or assumes any legal liability or responsibility for the accuracy, completeness, or usefulness of any information, apparatus, product, or process disclosed, or represents that its use would not infringe privately owned rights. Reference herein to any specific commercial product, process, or service by trade name, trademark, manufacturer, or otherwise does not necessarily constitute or imply its endorsement, recommendation, or favoring by the United States Government or any agency thereof. The views and opinions of authors expressed herein do not necessarily state or reflect those of the United States Government or any agency thereof. 


\section{DISCLAIMER}

Portions of this document may be illegible in electronic image products. Images are produced from the best available original document. 


\title{
AN ANALYSIS OF THE NAFA FLEET DATA BASE: PASSENGER CARS ONLY
}

\author{
Deborah Shonka \\ Research Assistants: \\ Ronald Lattanzio \\ Richard Weil
}

September 1980

\author{
ECONOMIC AND SYSTEMS ANALYSIS DIVIS!ON \\ NATIONAL CENTER FOR ANALYSIS OF ENERGY SYSTEMS \\ DEPARTMENT OF ENERGY AND ENVIRONMENT \\ BROOKHAVEN NATIONAL LABORATORY \\ ASSOCIATED UNIVERSITIES, INC. \\ Under Contract No. DE-ACO2-76CHOOO16 with the \\ UNITED STATES DEPARTMENT OF ENERGY
}




\section{DISCILATMER}

This report was prepared às an account of work sponsored by an agency of the Unitcd States Government. Neither the United States Government nor any agency thereof, nor any of theis empluyees, nor any of their contractors, subcontractors, or their employees, makes any warranty, express or implied, or assumes any legal liability or responsibility for the accuracy, completeness, or usefulness of any information, apparatus, product, or process disclosed, or represents that its use would not infringe privately owned rights. Reference herein to any specific commercial product, process, or service by trade name, trademark, manufacturer, or otherwise, does not necessarily constitute or imply its endorsement, recommendation, or favoring by the United States Government or any agency, contractor or subcontractor thereof. The views and opinions of authors expressed herein do not necessarily state or reflect those of the United States Government or any agency, contractor or subcontractor thereof.

Printed in the United States of America Available from

National Technical Information Service

U.S. Department of Commerce

5285 Port Royal Road

Springfield, VA 22161

Price: Printed Copy $\$ 6.00$; Microfiche $\$ 3.50$ 
To assess the potential market penetration of new vehicular concepts, it is first necessary to determine the current level of demand in terms of physical capabilities and economic constraints. The survey described in this report attempts to measure these characteristics for the fleet market sector in the U.S.

The data analyzed come from a survey taken in March 1979 of members of the National Association of Fleet Administrators (NAFA). Each respondent was asked to specify a set of characteristics for electric cars that would meet his specific fleet demands and assign the maximum price he would be willing to pay for each option. From the 139 responses, it is possible to relate the physical specifications of fleet vehicles to economic utility.

Two other reports deal with the simulator (CPEN) which was designed by BNL to estimate market penetration rates of new technologies in the fleet market, using the data base described within this report: Joseph R. Wagner, A Method for Estimating Technological Penetration Rates in Commercial Automobile Fleets, BNL 51312, May 1.980, and Richard Weil, Fleet Car Market Penetration Simulator (CPEN): A User's Guide, BNL 51286, August 1980 . 
The author would like to give special recognition to Joseph Wagner, formerly of Brookhaven National Laboratory, for his contributions to this report. His valuable comments and insights on an earlier draft were instrumental in shaping the final form of this report. I am also grateful to the other persons who offered comments on this earlier draft: Gretchen Kulp of Oak Ridge National Laboratory and Jack Allentuck of Brookhaven National Laboratory.

Finally, the author would like to thank Robert Berke and the . Nallund Assucialiuu ul Fleet Administrations. Without their aooiotance in distributing the survey, this report would not have been possible. 


\section{CONTENTS}

Abstract $\ldots \ldots \ldots \ldots \ldots \ldots \ldots \ldots \ldots \ldots \ldots \ldots \ldots \ldots \ldots \ldots \ldots \ldots \ldots \ldots$

Acknowledgments.................................... iv

Tables .......................................... vi

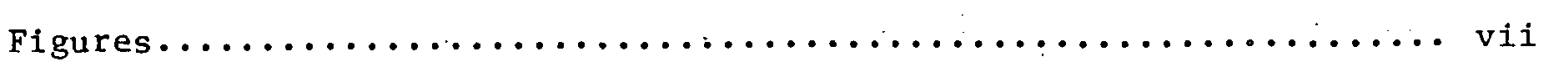

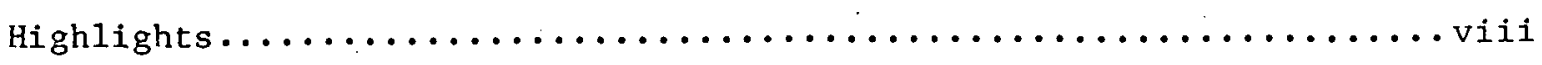

Introduction. .....................................

Description of Questionnarie and Sample...................

Characterization of the NAFA Data Base......................

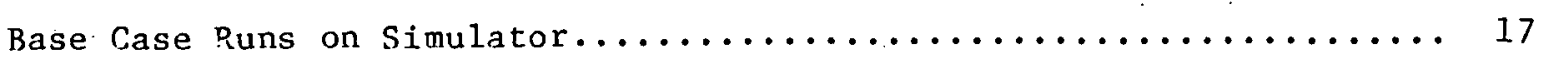

Caveats......................................... 19

Appendix A: NAFA Survey Questionnaire..................... 27 


\section{LIST OF TABLES}

Table 1 Distribution of NAFA Respondents and Fleet Cars

by Sector............................... 3

Table 2 . Electric Car Attributes...................... 4

Table 3 Breakdown of Desired Car Sizes................... 5

Table 4 . NAFA Fleet operator Demands by Sector............. 7

Table 5 Average Price of Selected Options as Determined by NAFA Fleet operators....................... 7

Table 6 Marginal Prices for Selected Options................ 9

Table 7 Seating Option vs Maximum Quoted by Respondent........ 10

Table 8 Trunk Option vs Maximum Price Quoted by Respondent..... 11

Table 9 Performance Option vs Maximum Price Quoted by

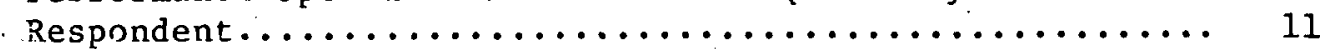

Table 10 Recharge Option vs Maximum Price Quoted by Respondent... 12

Table 11 Range Option vs Maximum Price Quoted by Respondent...... 13

Table 12 Heater Option vs Maximum Price Quoted by Respondent..... 14

Table 13 Air Conditioning Option vs Maximum Price Quoted by

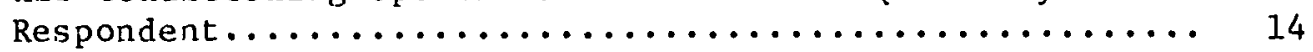

Table 14 Power Steering Option vs Maximum Price Quoted by

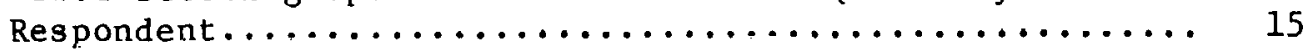

Table 15 Power Brakes Option vs Maximum Price Quoted by

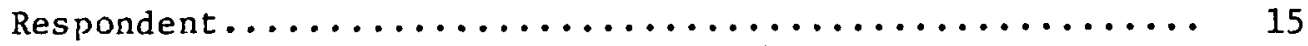

Table 16 Reliability Option vs Maximum Price Quoted by Respondent............................. 16 
Figure 1 Base Price of Car (Ex. Battery) Versus Market Penetration Rate............................ 20

Figure 2 Battery Price Versus Market Penetration Rate.......... 21

Figure 3 Vehicle Purchase Subsidy Versus Market Penetration Rate................................... 22

Figure 4 Recharge Time Versus Applicability Rate and Market Penetration Rates........................... 23

Figure 5 Trunk Space Versus Applicability Rates and Market Penetration Rates............................ 24

Figure 6 Number of Seats Versus Applicability. Rates and Market Penetration Rates....................... 25

Figure 7 Range Versus Applfcability Rates and Market Penetration Rates........................... 26 


\section{HIGHLIGHTS}

In 1979 a survey was mailed to the members of the National Association of Fleet Administrators (NAFA). The following conclusions are based on the response of 139 members, representing 84,559.fleet automobiles.

- Typical electric vehicle (EV) design required by the fleet operators:

4 seats

16 cubic foot/trunk

4 hours for battery recharge

192-mile range

Heater, air conditioning, power steering, and power brakes

Interstate highway capability

Max 13 unscheduled days in shop per year

- The operating demands and desired options varied by sector. This difference was statistically significant for the seat, trunk, range, and reliability options but not for the recharge option.

- Of the four sectors included in the survey, the police sector demands are significantly different from those of the other three sectors (government, husiness, utility).

- The fleet operators were on average willing to pay $\$ 52$ for a heater, $\$ 303$ for air conditioning, $\$ 85$ for power steering, $\$ 70$ for power brakes, and $\$ 278$ for interstate highway capability.

- The fleet operators were on average wiling to pay $\$ 179$ for each additional seat, $\$ 12$ for each additional cubic font in trunk space, and.$\$ 1.03$ for each additional mile of range. They would add to the purchase price $\$ 13$ for each hour decrease of recharge time and $\$ 11.50$ for each day's decrease in unscheduled time in the shop.

- There is no single overriding factor that influences applicability rates of $\mathrm{EVs}$. 


\section{INTRODUCTION}

To assess the potential market penetration of new vehicular concepts, it is first necessary to determine the current level of demand in terms of physical capabilities and economic constraints. The survey described in this report attempts to measure these characteristics for the fleet market in the U.S.

The fleet market is here defined as consisting of light-duty highway vehicles (i.e., passenger cars and trucks) operated by corporations and government agencies. Two of the most significant reasons for choosing the fleet Sector for this survey are that the fleet market is rather large, accounting for $13.7 \%$ of new car registrations in 1978 , * and that given their specific operating demands, fleets offer some special opportunities for vehicles with unusual or limited performance characteristics.**

In order to estimate market penetration rates of new technologies in the fleet market, Brookhaven National Laboratory (BNL) designed a simulator (CPEN) using the data base (NAFA data base) described in this report. A description of the simulator and a guide to its use are contained in the following two reports: Joseph R. Nagner, A Method for Estimating Technological Penetration Rates in Commercial Automobile Fleets, BNL 51312 prepared for the J.S. Department of Energy (DOE), May 1980; and Richard Weil, Fleet Car Market Penetration Simulator (CPEN): a User's Guide, BNL 51286 prepared for the U.S. Department of Energy, (DOE), August 1980 .

$\star_{1,504,809} \overline{l e e t}$ cars registered in 1978 (Automotive Fleet Fact Book, April 1980, p. 26) and 10,946,104 passenger cars registered in 1978 (MVMA Motor Vehicle Facts \& Figures 179, p. 24)

** See the following reports for a more detailed discussion: D.B. Shonka, Characteristics of Automotive Fleets in the United States 1966-1977, ORNL/TM-6449, September, 1978. Joseph R. Wagner, Fleet Operator Data Book (Suminer 1977 Data). Vol. I: National Data, BNL 50904, September 1979. 


\section{DESCRIPTION OF SAMPLE AND QUESTIONNAIRE}

The National Association of Fleet Administrators (NAFA) is a professional organization of fleet administrators, each operating a fleet of at least 25 cars or light trucks. In March 1979, the NAFA mailed questionnaires to its 1500 members.* Response was strictly voluntary and no follow-up letters were sent out. 139 usable responses were received, representing about $12 \%$ of the total automobiles managed by the NAFA membership $(84,559$ cars $)$. Of the total cars in market sectors spanned by NAFA (i.e., business, utility, police, and government), an estimated $1.8 \%$ were actually represented by those NAFA members responding to the survey sample. The NAFA sample is not a statistically designed probability sample. The type of fleet census needed to devise such a sample is not currently available.

The majority of the NAFA members (76.5\%) and the corresponding fleet survey respondents represent business fleets (see Table 1). However, three other market sectors are included: utilities (electric and gas), $1.2 \%$; police, $6 \%$; and governinent (non-police), $16.3 \%$. Taxi fleets, rental fleets, individually leased vehicles, and the federal government fleet are not represented by the NAFA membership and thus, correspondingly, by the NAFA survey. The distribution of the NAFA data base among the market sectors is compared in 'lable 1 with the national distribution of fleets as published in Bobit's Automotive Fleet Magazine.** The comparison indicates that the distributions are similar, having a correlation coefficient of .99. The utility sector appears to be underrepresented, though. The business sector, because of its size, exerts considerable influence over the aggregate measures.

*The questionnaire is given in Appendix A. **The Bobit data are by no means definitive, but they are the best source available for comparison. 
Table 1

DISTRIBUTION OF NAFA RESPONDENTS AND FLEET CARS BY SECTOR

\begin{tabular}{|c|c|c|c|c|}
\hline Sector & $\begin{array}{c}\text { NAFA } \\
\text { respondents }\end{array}$ & $\begin{array}{l}\text { NAFA } \\
\text { cars } \\
(\text { No. })\end{array}$ & $\begin{array}{r}\text { NAFA } \\
\text { cars } \\
(\%)\end{array}$ & $\begin{array}{c}\text { Bobit } \\
\text { cars }^{a} \\
(\%)\end{array}$ \\
\hline Police & 7 & 5,068 & 6.0 & 7.4 \\
\hline Government ${ }^{b}$ & 17 & 13,746 & $16 \cdot 3$ & 16.5 \\
\hline Utilities & 6 & 1,028 & 1.2 & 13.5 \\
\hline Business $c$ & 109 & 64,717 & 76.5 & 62.6 \\
\hline All sectors & 139 & 84,559 & 100.0 & 100.0 \\
\hline
\end{tabular}

The intent of the survey was twofold: 1) to make a vehicle count by type (car and light truck) and by state; 2) to determine the physical demands and economic constraints for ten options selected as those most likely to affect the acceptance of a new transportation technology, e.g., electric vehicles (EVs). Options specified were as follows:

(1) seating capacity, (2) trunk space, (3) performance capability, such as speed and acceleration sufficient to use limited access roads. like interstates, (4) recharge time, (5) range between refuelings, (6) heater, (7) air conditioner, (8) power steering, (9) power brakes, and (10) reliability (allowable annual number of unscheduled days in shop).

The respondent was asked to specify a set of characteristics for electric cars that would meet his spectfic fleet demands and assign the maximum price he would be willing to pay for each option. He was allowed to specify up to three different vehicles in addition to the base 
car.* The base car was given the following options: 2 seats, 5 cubic feet trunk space, 8-hour recharge time for a range of 30 miles, a maximum of 20 unscheduled days in shop per year, and no air conditioner, heater, power brakes or performance capability (see Table 2). The fleet managers indicated that this base car was sufficient for $7.2 \%$ of their vehicle stock. That is, $7.2 \%$ of the total sample could be replaced with EVs having. the base car's physical characteristics (w/o price considerations). A11 139 respondents specified at least one type of EV beyond the base car, 89 specified two EVs, and 49 specified three.

\begin{tabular}{lccc}
\hline & Table 2 & \\
& ELECTRIC CAR ATTRIBUTES & \\
& $\begin{array}{c}\text { NAFA } \\
\text { base } \\
\text { car }\end{array}$ & $\begin{array}{c}\text { Typical EV } \\
\text { characteris- } \\
\text { tics speci- } \\
\text { fied NAFA } \\
\text { respondents }\end{array}$ & $\begin{array}{c}1986 \\
\text { Target } \\
\text { EV }\end{array}$ \\
\hline Seats & 2 & 4 & 4 \\
Trunk (cubic feet) & 5 & 16 & 5 \\
Performance & No & Yes & Yes \\
Recharge time (hr) & 8 & 4 & 100 \\
Range (miles) & 30 & 192 & Yes \\
Heater & No & Yco & Yes \\
Air conditioner & No & Yes & Yes \\
Power steering & No & Yes & Yes \\
Power brakes & No & Yes & 0 \\
Reliability (days) & 20 & 13 & \\
\hline
\end{tabular}

In most cases, the delivered price on the base car (not including the price of the options) was fixed at $\$ 2,000$. However, the business sector questionnaire recipients were arbitrarily divided into thirds. The base price for the first third was set at $\$ 2,000$; the second third,

*The respondent was also asked to design electric trucks. This analysis is restricted to a discussion of the electric car designs. 
$\$ 4,000 ;$ and the last third, $\$ 6,000$. The final purchase price was calculated by adding the additional prices specified for each option to the base price.

After the respondent had specified characteristics for his car(s) and option prices, he was asked to designate what percentage of his total fleet could use each type of car. In order to get the number of cars involved, the respondents' total number of cars (as indicated in the vehicle census sheet filled out by the respondent) is then multiplied by each percentage. As noted above, there were 139 respondents with a combined fleet of 84,559 automobiles.

\section{CHARACTERIZATION OF THE NAFA DATA BASE}

As indicated in the previous section, each respondent was asked to design electric cars that would satisfy his particular fleet's demands. From these individual responses, it is possible to devise composite demands (see Table 2). That is, on the average, fleet operators indicated that they would need EVs with seating capacity for 4 people and with $15-\mathrm{ft}^{3}$ storage space in the trunk. The operating range should be about 200 miles with a 4-hr maximum recharge time and no more than 13 unscheduled days in the shop per year. Also, all of the options should be available: heater, air conditioner, power steering, power brakes, and sufficient speed and acceleration to use limited access roads (performance option). For this EV the fleet operators were willing to pay $\$ 5,700$. The extent to which the preferences of individual respondents deviated from this average vehicle is partially revealed by Table 3 , which shows the distribution of desired car sizes (i.e., seating capacities).

Table 3

BREAKDOWN OF DESIRED CAR SIZES

\begin{tabular}{ll}
\hline Size of car & $\%$ \\
\hline $\begin{array}{c}\text { Small } \\
(<5 \text { seats })\end{array}$ & 68.9 \\
$\begin{array}{l}\text { Metiun } \\
(=5 \text { seats }) \\
\text { Large } \quad \\
(>5 \text { seats })\end{array}$ & 16.8 \\
\end{tabular}


The operating demands and the required or desired options varied by sector (see Table 4). The averages of the attributes for each of the four sectors (government, police, business and utility) were clustered. The results indicate that, overall, the police sector is significantly different from the other 3 sectors. Utility, business, and government sectors tend to exhibit similar characteristics. Of course, these similarities and differences varied by option.

The number of seats required varied from a low of 3 for the utility sector to a high of 4 for the other 3 sectors. Utilizing an analysis of variance test,* the difference among sectors was considered statistically oignificant at the $95 \%$ confidence interval (C.I.).

There was considerable variation in average trunk capacity needed. The differences among sectors was statistically significant at the $99 \%$ C.I. For example, the utility sector indicated that they needed about 7.5 cubic feet of trunk space, whereas the government sector required 27.5 cubic feet. The design of the 1986 target EV allows for 5 cubic feet.

According to the analysis of variance test, there is no significant difference among market sectors in terms of desired recharge time. In terms of absolute numbers, the police sector placed the most emphasis on limited downtime due to recharge requirements $(1.7 \mathrm{hr})$ and the utility sector the least $(5.6 \mathrm{hr})$. The other sectors required 4-hr recharge times. The 1986 target batteries require about 8 hours to recharge.

There was a statistically significant difference (at the $99 \%$ C.I.) in range requirements by sector. The government sector requested a range of about $100 \mathrm{miles}$ while the police sector required a 436-mile range. The range on premium EVs in service today is 100 miles.

Finally, importance of the reliability of the EV varied significantly (at the $99 \%$ C.I.) among the sectors. The business sector objected most to unscheduled days in the shop ( $\max =12$ days). This is high in comparison to new ICE cars which are not expected to spend many days in the

*The Analysis of Variance (ANOVA) uses a $F$ ratio test to determine if statistical differences exist. 
Table 4

NAFA FLEET OPERATOR DEMANDS BY SECTOR

\begin{tabular}{|c|c|c|c|c|c|c|c|}
\hline Sector & $\begin{array}{l}\text { Av } \\
\text { Seats } \\
\end{array}$ & $\begin{array}{l}\text { Av trunk } \\
\left(\mathrm{ft}^{3}\right)\end{array}$ & $\begin{array}{c}\text { Av recharge } \\
(\mathrm{hr})\end{array}$ & $\begin{array}{l}\text { Av range } \\
\text { (mile) }\end{array}$ & $\begin{array}{l}\text { Av reliability } \\
\text { (days) }\end{array}$ & $\begin{array}{l}\text { Av car } \\
\text { price }\end{array}$ & $\begin{array}{c}\text { No } . \\
\text { respon- } \\
\text { dents } \\
\end{array}$ \\
\hline Police & 4.1 & 16.5 & 1.7 & 436 & 15 & $\$ 6202$ & 7 \\
\hline Government & 4.4 & 27.5 & 4.1 & 101 & 15 & 3792 & 17 \\
\hline Utilities & 3.0 & 7.5 & 5.6 & 150 & 16 & 4128 & 6 \\
\hline Business & 4.0 & 12.6 & 4.2 & 166 & 12 & 6048 & 109 \\
\hline All sectors & 4.1 & $16.2 \ldots$ & 4.0 & 192 & 13 & 5667 & 139 \\
\hline
\end{tabular}

ancluding driver.

Table 5

AVERAGE PRICE OF SELECTED OPTIONS AS DETERMINED BY NAFA FLEET OPERATORS

\begin{tabular}{|c|c|c|c|c|c|c|}
\hline \multirow[b]{2}{*}{ Sector } & \multicolumn{6}{|c|}{ OPTION } \\
\hline & Heater & $\begin{array}{c}\text { Air } \\
\text { conditioner }\end{array}$ & $\begin{array}{c}\text { Power } \\
\text { steering }\end{array}$ & $\begin{array}{r}\text { Power } \\
\text { brakes }\end{array}$ & Performance & $\begin{array}{l}\text { No. } \\
\text { respondents }\end{array}$ \\
\hline Police & $\$ 70$ & $\$ 231$ & $\$ 152$ & $\$ 111$ & $\$ 209$ & 7 \\
\hline Government & 83 & 179 & 70 & 48 & 298 & -17 \\
\hline Utilities & 32 & 238 & 60 & 36 & 249 & 6 \\
\hline Business & 55 & 275 & 68 & 57 & 337 & 109 \\
\hline A11 sectors & 52 & 303 & 85 & 70 & 278 & 139 \\
\hline $\begin{array}{l}\text { ICE retail } \\
\text { price }\end{array}$ & $\begin{array}{l}\text { st } \\
\text { Standard }\end{array}$ & 500 & 150 & 65 & Standard & \\
\hline
\end{tabular}

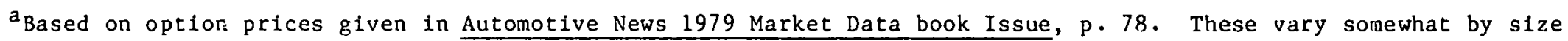
of car and manufacturer. 
shop for repairs except for regularly scheduled maintenance. However, this seems to be a moot point as the state-of-the-art EVs are expected to be at least as reliable as ICEs.

The respondents were also asked to indicate the maximum price they would be willing to pay for each option. The prices for five options are given by sector in Table 5. On the average, the fleet operators were willing to pay $\$ 52$ for a heater, which is usually standard equipment (i.e., included in the base price) on ICE cars. An air conditioner (A/C) was worth $\$ 303$. The power steering option was valued at $\$ 85$ and power brakes at $\$ 70$. The performance option, defined as speed and acceleration sufficient to use limited access roads such as interstates and expressways, was worth $\$ 278$ on the average. This option is standard on current ICE cars. The fleet operators valued the $A / C$ and power steering options below suggested retail prices. This can be explained from the observation that fleet operators frequently obtain substantial discounts froin list prices.

Using regression analysis, marginal prices were calculated for the other five options,* and are presented in Table 6 . On the average; the fleet operators were willing to pay $\$ 179$ for each additional seat beyond the two available in the base car. This varied from a low of $\$ 150$ indicated by police administrators to a high of $\$ 855$ indicated by utilities. On the average, trunk space is valued at $\$ 12$ per cubic feet beyond the 5 cubic feet available in the base car. Once again utilities were willing to pay a premium $\$ 57 / \mathrm{ft}^{3}$, whereas trunk space was valued at only $\$ 11 / \mathrm{ft}^{3}$ by the business fleet administrators.

The fleet operators were willing to pay, on the average, $\$ 13$ for each one hour reduction in recharge tine from the 8-hour refueling time required by the base car. The utility sector was willing to pay the most for reductions in the 8-hour recharge time of the basc car, though they required the least amount of actual recharge time reduction. Fleet operators were willing to pay about $\$ 1.00$ per mile for range greater than the 30 miles offered by the base car. Business fleet operators would

*These numbers are based on the prices indicated for optional car 1 only. 
Table 6

MARGINAL PRICES FOR SELECTED. OPTIONS ${ }^{a}$

Marginal prices (\$) per unit

\begin{tabular}{lcccccc}
\hline Sector & $\begin{array}{l}\text { No. } \\
\text { seats } \\
\left(\$ / \text { seats }^{b}\right.\end{array}$ & $\begin{array}{l}\text { Trunk } \\
\text { space } \\
\left(\$ / \mathrm{ft}^{3}\right)\end{array}$ & $\begin{array}{c}\text { Reduction in } \\
\text { recharge time } \\
(\$ \mathrm{hr}))\end{array}$ & $\begin{array}{c}\text { Range } \\
(\$ / \mathrm{miles})\end{array}$ & $\begin{array}{c}\text { Improved } \\
\text { reliability } \\
(\$ / \text { days })\end{array}$ & $\begin{array}{c}\text { No. } \\
\text { respondents }\end{array}$ \\
\hline Police & $\$ 150$ & $\$ 17$ & $\$ 15$ & $\$ 1.75$ & $\$ 18.24$ & 7 \\
Government & 207 & 20 & 8 & 1.31 & 7.30 & 17 \\
Utilities & 855 & 57 & 18 & 3.32 & 2.55 & 6 \\
Business & 156 & 11 & 14 & .5 & 12.46 & 109 \\
All sectors & 179 & 12 & 13 & 1.03 & 11.50 & 139 \\
\hline
\end{tabular}

a Based on the prices indicated for optional car 1 only.

bIncluding driver.

only pay 50ф/mile; utilities, $\$ 3.32 / \mathrm{mile.} \mathrm{Improved} \mathrm{reliability} \mathrm{was} \mathrm{worth,} \mathrm{on}$ the average, $\$ 11.50$ per one day reduction in number of unscheduled days in repair shop (base car equal to 12 days). Reliability was worth most to police $(\$ 18 /$ day $)$ and least to utilities $(\$ 2.55)$. From this analysis, it appears that the utility sector is the least constrained by economic considerations.

Further regression analysis based on optional car 1 only was done to determine the elasticity of five options: seating, trunk space, recharge time, range, and reliability. The results indicated that all five options were relatively inelastic. That is, the price did not necessarily affect the demand.

Tables 7 through 16 present the cross tabulations for each of the ten options versus the maximum price for each option (as determined by the respondents). The cumulative frequencies calculated for each option provide guidelines for determining the eventual market penetration. For example, to penetrate at least $50 \%$ of the fleet market (as represented by NAFA) a car would need the following attributes: 


\begin{tabular}{|c|c|c|c|c|c|c|c|c|}
\hline . & & & LE 7: $\begin{aligned} & \text { Seating } \\
& \text { Percent }\end{aligned}$ & $\begin{array}{l}\text { Option vs Maximu } \\
\text { of Vehicles (No. }\end{array}$ & $\begin{array}{l}\text { 10. Price Qusted by } \\
\text { of Vehicles) }\end{array}$ & Zespondent & & \\
\hline No. of seats & 0 & . $\$ 1$ to $\$ 150$ & $\$ 151$ to $\$ 250$ & $\$ 251$ to $\$ 400$ & $\$<01$ to $\$ 800$ & $\$ 800$ plus & $\begin{array}{l}\text { Relative } \\
\text { frequency }\end{array}$ & $\begin{array}{r}\text { Cumulative } \\
\text { frequency }\end{array}$ \\
\hline 2 & $\begin{array}{l}15.8 \\
(13255)\end{array}$ & $\begin{array}{l}0.0 \\
(0)\end{array}$ & $\begin{array}{l}0.0 \\
(39)\end{array}$ & $\begin{array}{l}0.0 \\
(0)\end{array}$ & $\begin{array}{l}c .0 \\
(0)\end{array}$ & $\begin{array}{c}0.2 \\
(142)\end{array}$ & $\begin{array}{l}16.0 \\
(1346)\end{array}$ & 16.0 \\
\hline 3 & $(131)$ & $\begin{array}{c}0.5 \\
(436)\end{array}$ & $\begin{array}{c}0.3 \\
(239)\end{array}$ & $\begin{array}{l}0.8 \\
(714)\end{array}$ & $\underset{(50)}{E .1}$ & $\begin{array}{l}0.0 \\
(0)\end{array}$ & $\begin{array}{c}1.9 \\
(1569)\end{array}$ & 17.9 \\
\hline 4 & $\begin{array}{c}7.0 \\
(5868)\end{array}$ & $\begin{array}{c}5.8 \\
\vdots 4872)\end{array}$ & $\begin{array}{c}9.9 \\
(8330)\end{array}$ & $\begin{array}{c}6.0 \\
(5029)\end{array}$ & $\begin{array}{c}9.8 \\
(7423)\end{array}$ & $\begin{array}{c}13.6 \\
(11429)\end{array}$ & $\begin{array}{c}51.0 \\
(42951)\end{array}$ & 68.9 \\
\hline 5 & $\begin{array}{c}3.4 \\
(2375)\end{array}$ & $\begin{array}{c}4.3 \\
(3580)\end{array}$ & $\begin{array}{c}1.2 \\
(1047)\end{array}$ & $\begin{array}{c}4.2 \\
(3541)\end{array}$ & 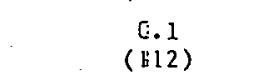 & $\begin{array}{c}3.5 \\
(2940)\end{array}$ & $\begin{array}{c}16.8 \\
(14096)\end{array}$ & 85.7 \\
\hline 6 & $\begin{array}{l}0.3 \\
(278)\end{array}$ & $\begin{array}{r}0.1 \\
(96)\end{array}$ & $\begin{array}{c}1.4 \\
(1153)\end{array}$ & $\begin{array}{c}1.4 \\
(1181)\end{array}$ & $\begin{array}{c}5.8 \\
(4 \varepsilon 79)\end{array}$ & $\begin{array}{c}4.5 \\
(3761)\end{array}$ & $\begin{array}{c}13.5 \\
(11348)\end{array}$ & . $\quad 99.2$ \\
\hline 7 plus & $\begin{array}{l}0.1 \\
(54)\end{array}$ & $\begin{array}{l}0.0 \\
(0)\end{array}$ & $\begin{array}{l}0.0 \\
(j)\end{array}$ & $\begin{array}{l}0.0 \\
(9)\end{array}$ & $\begin{array}{c}(.2 \\
(161)\end{array}$ & $\begin{array}{c}0.6 \\
(519)\end{array}$ & $\begin{array}{c}0.8 \\
. \quad(741)\end{array}$ & $=100.0$ \\
\hline Overall & $\begin{array}{c}26.7 \\
(22459)\end{array}$ & $\begin{array}{c}10.7 \\
(8984)\end{array}$ & $\begin{array}{c}12.8 \\
(10809)\end{array}$ & $\begin{array}{c}12.4 \\
(10472)\end{array}$ & $\begin{array}{c}15.0 \\
(12 \in 25)\end{array}$ & $\begin{array}{c}22.3 \\
(18792)\end{array}$ & $\begin{array}{l}100.00 \\
(84141)\end{array}$ & \\
\hline
\end{tabular}

Note: Totals may not agree due to rodnding.

aForm of Question: Seating Capacticy testred (including driver) 


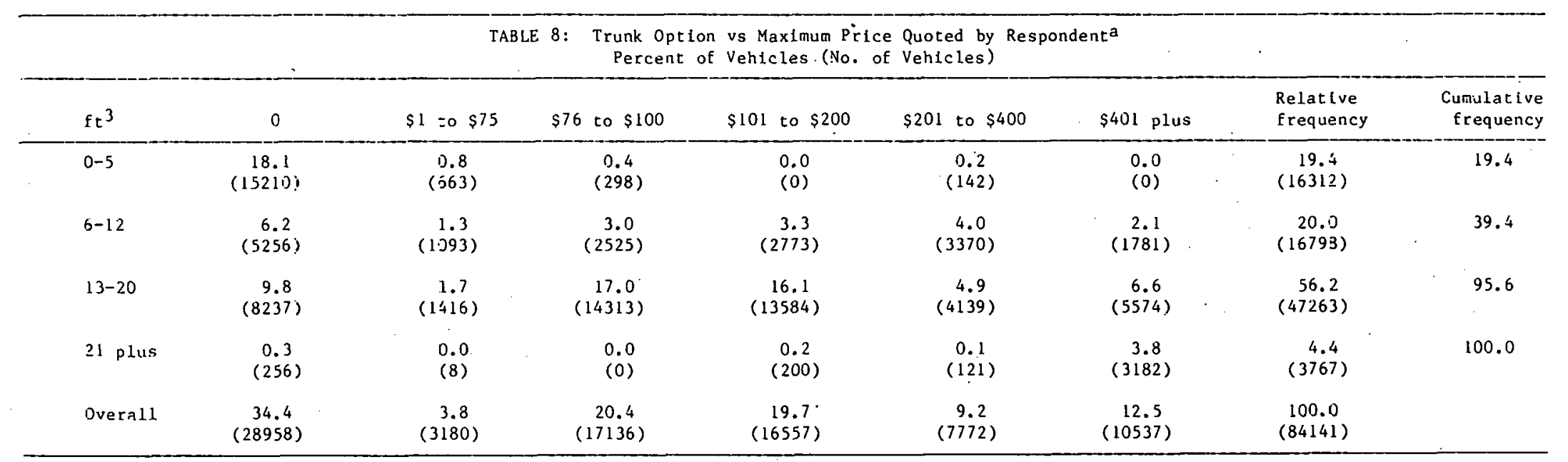

Note: Totals may not agree due to rounding.

TABLE 9: Performance Option vs Maximum Price Quoted by Respondent ${ }^{a}$ Percent of vehicles (No. of vehicles)

\begin{tabular}{|c|c|c|c|c|c|c|c|c|}
\hline & 0 & $\$ 1$ to $\$ 150$ & $\$ 151$ to $\$ 250$ & $\$ 251$ to $\$ 400$ & $\$ 401$ to $\$ 800$ & $\$ 801$ plus & $\begin{array}{l}\text { Relative } \\
\text { frequency }\end{array}$ & $\begin{array}{l}\text { Cumulative } \\
\text { frequency }\end{array}$ \\
\hline No & $\begin{array}{c}10.8 \\
(9058)\end{array}$ & $\begin{array}{l}0.0 \\
(0)\end{array}$ & $\begin{array}{l}0.0 \\
(0)\end{array}$ & $\begin{array}{l}0.0 \\
(0)\end{array}$ & $\begin{array}{l}0.0 \\
(j)\end{array}$ & $\begin{array}{l}0.0 \\
(0)\end{array}$ & $\begin{array}{c}10.3 \\
(9058)\end{array}$ & 10.8 \\
\hline Yes & $\begin{array}{c}13.4 \\
(16331)\end{array}$ & $\begin{array}{c}22.4 \\
(18868)\end{array}$ & $\begin{array}{c}15.1 \\
(12721)\end{array}$ & $\begin{array}{c}11.5 \\
(3696)\end{array}$ & $\begin{array}{c}11.7 \\
(9849)\end{array}$ & $\begin{array}{c}9.1 \\
(7618)\end{array}$ & $\begin{array}{c}39.2 \\
(75083)\end{array}$ & 100.0 \\
\hline Overall & $\begin{array}{c}30.2 \\
(25390)\end{array}$ & $\begin{array}{c}22.4 \\
(18867)\end{array}$ & $\begin{array}{c}15.1 \\
(12721)\end{array}$ & $\begin{array}{c}11.5 \\
(9696)\end{array}$ & $\begin{array}{c}11.7 \\
(9849)\end{array}$ & $\begin{array}{c}9.1 \\
(7618)\end{array}$ & $\begin{array}{c}100.0 \\
(34141)\end{array}$ & \\
\hline
\end{tabular}

Note: Totals may not agree due to rounding.

aForm of question: Speed and acceleration sufficlent to use limited-access roads (1.e., interstates, expressways) (yes or no). Maximum price you would be willing to pay for this option 


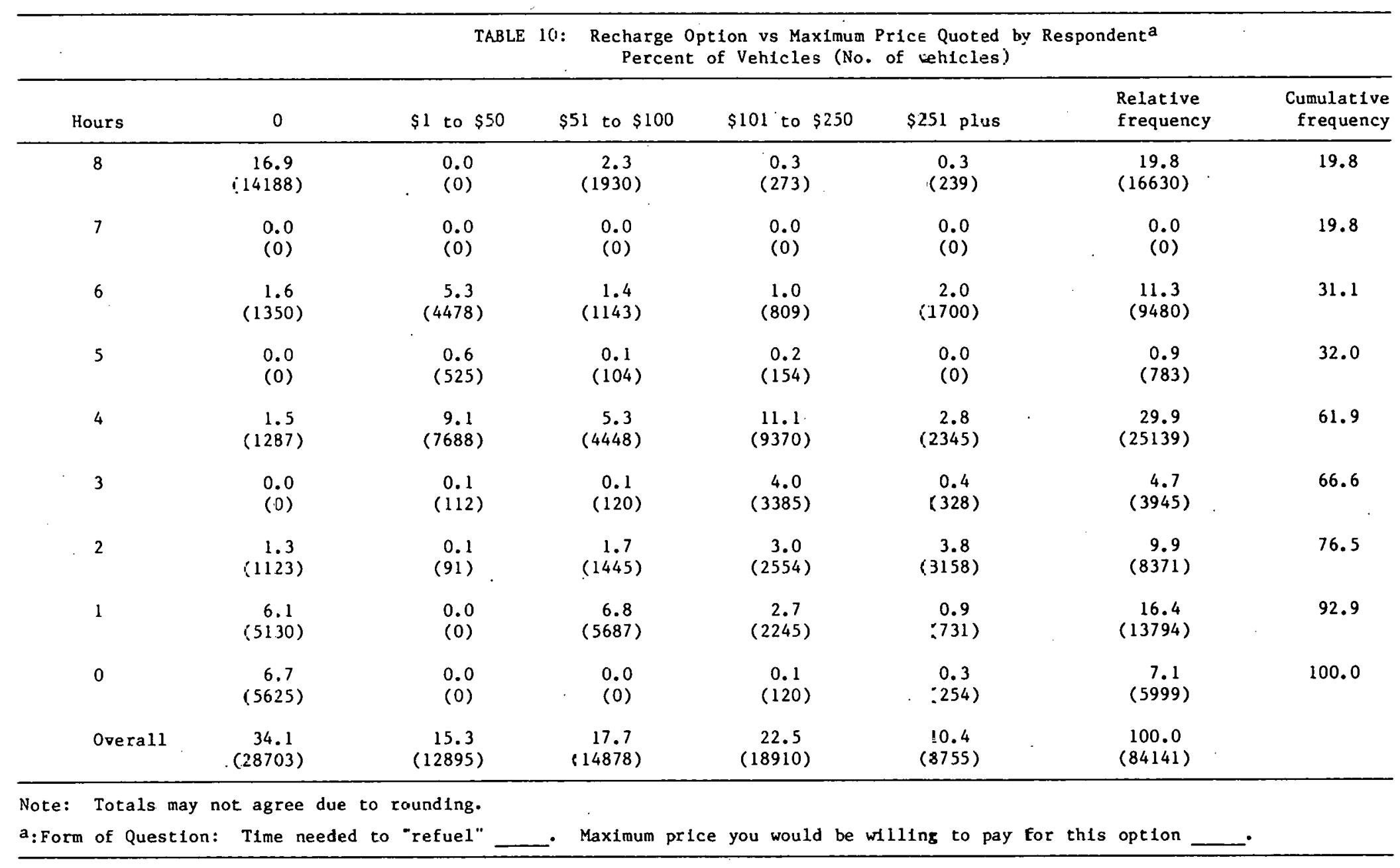




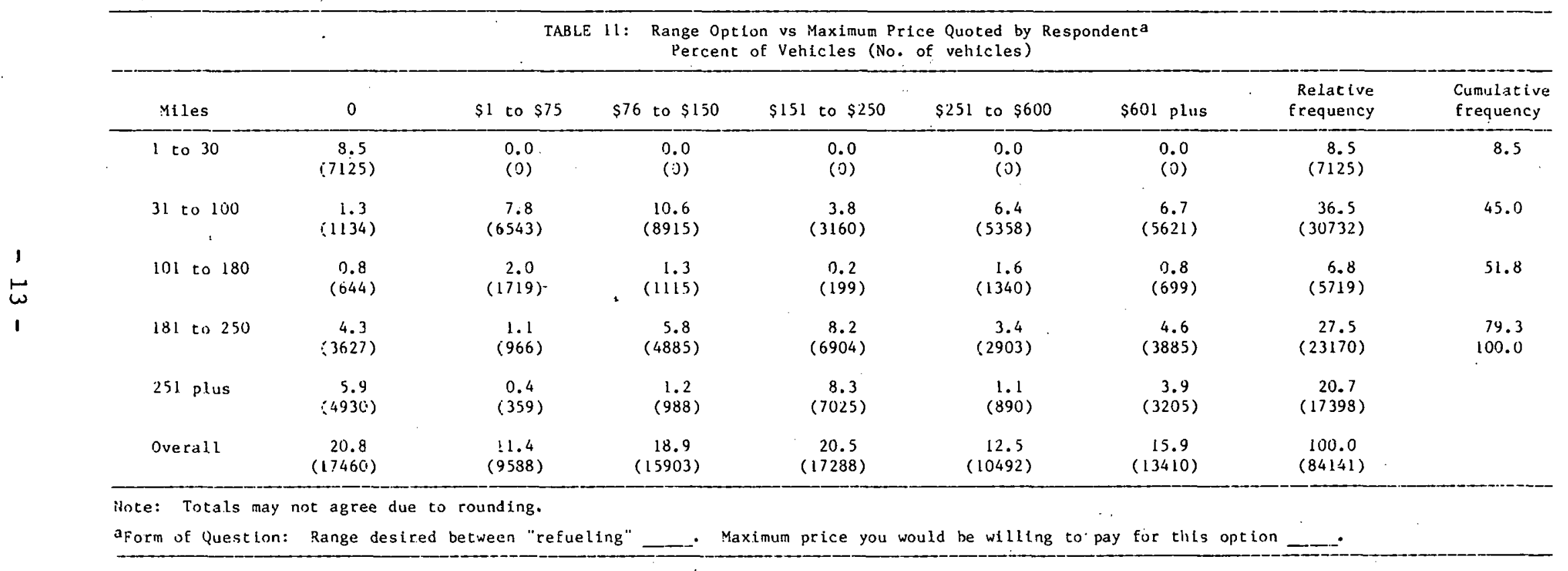




\begin{tabular}{|c|c|c|c|c|c|c|c|}
\hline & \multicolumn{7}{|c|}{$\begin{array}{c}\text { TABLE 12: Heater 0ption vs Maximum Price Quoted by Respondenta } \\
\text { Percent of Vehicles (No. of vehci:es) }\end{array}$} \\
\hline & 0 & $\$ 1$ to $\$ 40$ & $\$ 41$ to $\$ 50$ & $\$ 51$ to $\$ 100$ & $\$ 101$ Plus & $\begin{array}{l}\text { Relative } \\
\text { frequency }\end{array}$ & $\begin{array}{l}\text { Cumulative } \\
\text { frequency }\end{array}$ \\
\hline No & $\begin{array}{c}12.4 \\
(10397)\end{array}$ & $\begin{array}{l}0.0 \\
(0)\end{array}$ & $\begin{array}{l}0.0 \\
(0)\end{array}$ & $\begin{array}{l}0.0 \\
(0)\end{array}$ & $\begin{array}{l}0.10 \\
(0)\end{array}$ & $\begin{array}{r}12.4 \\
(10397\end{array}$ & 12.4 \\
\hline Yes & $\begin{array}{c}22.4 \\
(18351)\end{array}$ & $\begin{array}{c}13.4 \\
(11278)\end{array}$ & $\begin{array}{c}20.9 \\
(17607)\end{array}$ & $\begin{array}{c}21.0 \\
(17689)\end{array}$ & $\begin{array}{c}9.9 \\
(83199\end{array}$ & $\begin{array}{c}87.6 \\
(73744)\end{array}$ & 100.0 \\
\hline Overall & $\begin{array}{c}34.8 \\
(29248)\end{array}$ & $\begin{array}{c}13.4 \\
(11278)\end{array}$ & $\begin{array}{c}20.9 \\
(17607)\end{array}$ & $\begin{array}{c}21.0 \\
(17689)\end{array}$ & $\begin{array}{c}9.9 \\
(8317)\end{array}$ & $\begin{array}{c}100.0 \\
(84141)\end{array}$ & $\cdot$ \\
\hline
\end{tabular}

Note: Totals may not agree due to rounding

aform of Question: Passenger Compartment Heater (ges or no). Maximum price you wruld be wllling to pay for this option

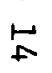

TABLE 13: Air Conditioning Option vs Naximum Price Quoted by Respondent ${ }^{a}$

Percent of Vehicles (No. of vehic-es)

\begin{tabular}{|c|c|c|c|c|c|c|c|c|}
\hline . & 0 & $\$ 1$ & to $\$ 300$ & $\$ 301$ to $\$ 400$ & $\$ 401$ to $\$ 475$ & $\$ 476$ pius & $\begin{array}{l}\text { Relative } \\
\text { frequency }\end{array}$ & $\begin{array}{l}\text { Cumulative } \\
\text { frequency }\end{array}$ \\
\hline No & $\begin{array}{c}23.7 \\
(19947)\end{array}$ & & $\begin{array}{l}0.0 \\
(0)\end{array}$ & $\begin{array}{l}0.0 \\
(0)\end{array}$ & $\begin{array}{l}0.0 \\
(0)\end{array}$ & $\begin{array}{l}0.0 \\
(0)\end{array}$ & $\begin{array}{c}23.7 \\
(19947)\end{array}$ & 23.7 \\
\hline Yes & $\begin{array}{c}2.6 \\
(2148)\end{array}$ & & $\begin{array}{l}0.0 \\
(0)\end{array}$ & $\begin{array}{c}37.5 \\
(31594)\end{array}$ & $\begin{array}{c}16.5 \\
(13918)\end{array}$ & $\begin{array}{c}19.6 \\
(16534)\end{array}$ & $\begin{array}{c}76.3 \\
(64194)\end{array}$ & 100.0 \\
\hline Overall & $\begin{array}{c}26.3 \\
(22095)\end{array}$ & & $\begin{array}{l}0.0 \\
(0)\end{array}$ & $\begin{array}{c}37.5 \\
(31594)\end{array}$ & $\begin{array}{c}16.5 \\
(13918)\end{array}$ & $\begin{array}{c}19.6 \\
(16534)\end{array}$ & $\begin{array}{c}100.0 \\
(84141)\end{array}$ & \\
\hline
\end{tabular}

Note: Totals may not agree due to rounding

a Form of Question: Air conditioning (yes or no). Maximum price you would be willing to pay for this option 


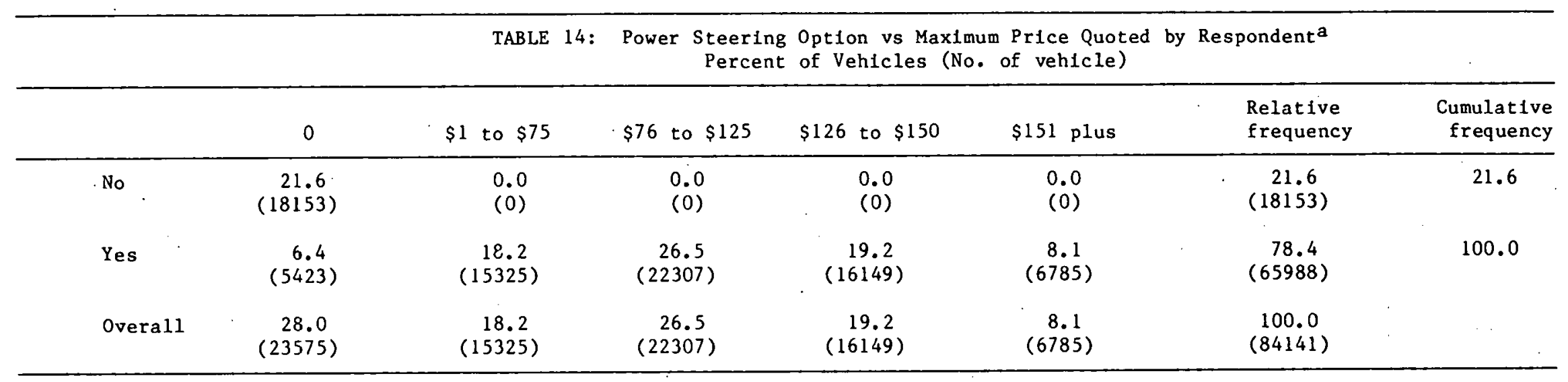

Note: Totals may not agree due to rounding.

aForm of Question: Power Steering (yes or no). Maximum price you would be willing to pay for this option 1 光

TABLE 15: Power Brakes Option vs Maximum Price quoted by Respondenta Percent of Vehicles (No. of vehicles)

\begin{tabular}{|c|c|c|c|c|c|c|c|}
\hline$\cdot$ & 0 & $\$ 1$ to $\$ 50$ & $\$ 51$ to $\$ 65$ & $\$ 66$ to $\$ 75$ & $\$ 76$ plus & $\begin{array}{l}\text { Relative } \\
\text { frequency }\end{array}$ & $\begin{array}{l}\text { Cumulative } \\
\text { frequency }\end{array}$ \\
\hline No & $\begin{array}{c}23.2 \\
(19509)\end{array}$ & $\begin{array}{l}0.0 \\
(0)\end{array}$ & $\begin{array}{l}0.0 \\
(0)\end{array}$ & $\begin{array}{l}0.0 \\
(0)\end{array}$ & $\begin{array}{l}0.0 \\
(0)\end{array}$ & $\begin{array}{c}23.2 \\
(19509)\end{array}$ & 23.2 \\
\hline Yes & $\begin{array}{c}10.6 \\
(8916)\end{array}$ & $\begin{array}{c}10.2 \\
(8565)\end{array}$ & $\begin{array}{c}13.7 \\
(11505)\end{array}$ & $\begin{array}{c}25.3 \\
(21263)\end{array}$ & $\begin{array}{c}17.1 \\
(14383)\end{array}$ & $\begin{array}{c}76.8 \\
(64632)\end{array}$ & 100.0 \\
\hline Overall & $\begin{array}{c}33.8 \\
(28425)\end{array}$ & $\begin{array}{c}10.2 \\
(8565)\end{array}$ & $\begin{array}{c}13.7 \\
(11505)\end{array}$ & $\begin{array}{c}25.3 \\
(21263)\end{array}$ & $\begin{array}{c}17.1 \\
(14383)\end{array}$ & $\begin{array}{c}100.0 \\
(84141)\end{array}$ & \\
\hline
\end{tabular}

Note: Totals may not agree due to rounding.

aForm of Question: Power Brakes (yes or no). Maximum price you would be willing to pay for this option 


\begin{tabular}{|c|c|c|c|c|c|c|c|c|}
\hline & \multirow[b]{2}{*}{ Days } & & \multicolumn{4}{|c|}{$\begin{array}{l}\text { Reliab:lity Option vs Maximum Price Quoted sy Respondent } \\
\text { Percent of Vehicles (No. of vehicles). }\end{array}$} & \multirow[b]{2}{*}{$\begin{array}{l}\text { Relat tve } \\
\text { f requency }\end{array}$} & \multirow[b]{2}{*}{$\begin{array}{l}\text { Cumulative } \\
\text { frequency }\end{array}$} \\
\hline & & 0 & $\$ 1$ to $\$ 100$ & $\$ 101$ to $\$ 200$ & \multicolumn{2}{|l|}{$\$ 201$ plus } & & \\
\hline & $18-20$ & $\begin{aligned} 39.5 \\
(33258\end{aligned}$ & $\begin{array}{l}0.8 \\
(736)\end{array}$ & $\begin{array}{c}0.9 \\
(725)\end{array}$ & $\begin{array}{c}2.7 \\
(230 C)\end{array}$ & & $\begin{array}{c}44.0 \\
(36989)\end{array}$ & 44.0 \\
\hline & $15-17$ & $\begin{array}{l}0.1 .5 \\
(i)\end{array}$ & $\begin{array}{c}1.7 \\
(1427)\end{array}$ & $\begin{array}{l}0.2 \\
(149)\end{array}$ & 0.0 & & $\begin{array}{c}1.9 \\
(1576)\end{array}$ & 45.9 \\
\hline & $12-14$ & $\begin{array}{c}2.3 \\
(19.3 \\
19\end{array}$ & $\begin{array}{c}1.9 \\
(1607)\end{array}$ & $\begin{array}{c}1.6 \\
(1.328)\end{array}$ & $\begin{array}{l}0.0 \\
(j)\end{array}$ & & $\begin{array}{c}5.8 \\
(4882)\end{array}$ & 51.7 \\
\hline$a$ & $9-11$ & $\begin{array}{c}5.3 \\
(44.730\end{array}$ & $\begin{array}{l}10.3 \\
(3700)\end{array}$ & $\begin{array}{c}5.2 \\
(4359)\end{array}$ & $\begin{array}{c}1.0 \\
(802)\end{array}$ & & $\begin{array}{c}21.8 \\
(18333)\end{array}$ & 73.5 \\
\hline I & $6-8$ & $\begin{array}{c}1.4 \\
(1146)\end{array}$ & $\begin{array}{c}2.8 \\
(2377)\end{array}$ & $\begin{array}{c}0.2 \\
(136)\end{array}$ & $\begin{array}{c}2.5 \\
(2105)\end{array}$ & & $\begin{array}{c}6.9 \\
(5764)\end{array}$ & 80.4 \\
\hline & $3-5$ & $\begin{array}{c}1.8 \\
(1527)\end{array}$ & $\begin{array}{c}1.5 \\
(1: 83)\end{array}$ & $\begin{array}{c}2.2 \\
(1859)\end{array}$ & $\begin{array}{c}2.5 \\
(2218)\end{array}$ & & $\begin{array}{c}8.3 \\
(6988)\end{array}$ & 88.7 \\
\hline & $0-2$ & $\begin{array}{c}3.1 \\
(2514)\end{array}$ & $\begin{array}{l}0.0 \\
0.0)\end{array}$ & $\begin{array}{c}0.6 \\
(546)\end{array}$ & $\begin{array}{c}7.7 \\
(5453)\end{array}$ & & $\begin{array}{c}11.4 \\
(9611)\end{array}$ & 100.0 \\
\hline & Overall & $\begin{array}{c}53.4 \\
(44965)\end{array}$ & $\begin{array}{c}19.3 \\
(16: 99)\end{array}$ & $\begin{array}{c}10.8 \\
(9101)\end{array}$ & $\begin{array}{c}16.5 \\
(13875)\end{array}$ & & $\begin{array}{c}100.0 \\
(84141)\end{array}$ & \\
\hline
\end{tabular}

Note: Totals may not agree due to rotneing.

aform of Question: fllowable annual nuaber of unschedu.ed days in shop 
4 seats $(69 \%)$

13 to 20 cubic feet ( $96 \%)$

performance capability ( $89 \%)$

4-hr max recharge (62\%)

101 to $180-m i l e$ range (52\%)

heater $(88 \%)$

air conditioner $(76 \%)$

power steering (78\%)

power brakes $(77 \%)$.

maximum of 12 to 14

unscheduled repair days ( $52 \%$ )

The numbers in parentheses represent the percent of NAFA survey that would be captured if that option were available. These are in absolute terms. No allowance is made for tradeoffs. That is, in reality, the respondent may be willing to "trade off" a few cubic feet of trunk space for an air conditioner.

\section{BASE CASE RUNS ON CPEN SIMULATOR}

As indicated in the introduction to this report, a simulator (CPEN) has been designed to use the NAFA data base to estimate the market penetration rates of new technologies in the fleet market. This section discusses some of the curves that have been generated using CPEN.

CPEN produces two types of rates: applicability rates and market penetration rates. The applicability rates are generated by comparing the physical attributes of the input vehtcle (in our case, the 1986 target EV) to the required physical capabilities specified for cars operated by the individul NAFA respondents. The market penetration rates are calculated on the basis of both physical and economic considerations. That is, for all EVs that are physically applicable to a particular respondent, life-cycle costs including purchase price are calculated for both the EV and a comparable ICE. The respondent is assumed to purchase the vehicle whose purchase price is lower. If purchase prices are comparable, then the choice depends on the total life-cycle cost. Finally, if the purchase price exceeds certain limits set by the respondent, he is said to defer purchasing altogether. 
The simulator was initially run with a vehicle corresponding to the 1986 Target EV (see Table 1), with a base price of $\$ 6500$, battery price of $\$ 1355$, and no subsidy. Based on the NAFA survey data results, this EV design had an applicability rate of $12 \%$ but a zero penetration rate and thus no actual retail sales.

A series of curves were generated to indicate the sensitivity of these rates to changes in both physical characteristics and economic considerations. They are presented in Figures 1 through 7 . Each figure deals with changes in one specific variable, while all others are held constant.

Figure 1 shows the market penetration rate versus the base price of the car. As indicated above, this car offered at $\$ 6500$ would have zero buyers. If the price was decreased by $\$ 2500$, the penetration rate would increase to $3 \%$. If the vehicle was virtually free, the vehicle would be selected by on $1 y$ $9 \%$ of the NAFA respondents. Changes in battery price have even less effect (see Figure 2). Going from a battery price of $\$ 1355$ to 0 would only increase the market penetration to $2 \%$. Increasing the subsidy from 0 to $\$ 2000$, with all else held constant, would increase market penetration by $3 \%$ (see Figure 3 ). of course, this has the same effect as redicing the vehicle price by $\$ 2000$. Note though that a given dollar reduction in battery price has a different effect than an equivalent reduction in vehicle price because of the differential way in which these alternatives affect life-cycle costs (See BNL 51312).

Changes in the physical characteristics of the EV generally did not result in changes in the market penetration rate, which remained at or near zero. Figures 4 to 7 display changes in applicability rates based. on changes in physical characteristics. Figure 4 indicates that a reduction in the required recharge time from 8 to 0 hours would result in an increase of $5 \%$ in terms of applicability ( 12 to $17 \%$ ). The applicability rate peaks at about $17 \%$ for a maximum $30 \mathrm{ft}^{3}$ in terms of trunk capacity (see Figure 5). Increases in seat capacity have little effect on applicability rates (see Figure 6), while an increase in range from 50 to 300 miles would result in about $3 \%$ increase in applicability (10 to $13 \%$, see Figure 7). 
It is clear from this limited analysis that there is no single overriding factor that influences applicability rates of EVs. Dramatic increase in specific capabilities result in only minimal increases in applicability rates. For example, while omission of AC would result in substantial reduction of user markets, inclusion does not guarantee a good acceptance rate. The fleet administrators are looking at the whole package - options, performance, and price.

\section{CAVEATS}

The data base described in this report has many drawbacks. The survey did not represent a statistically designed probability sample. Nor were the data weighted to correct for potential sampling errors.* The response rate was very low. From the responses, it appears that the maximum acceptable option prices specified by many of the fleet administrators were unrealistically low. Also, some of the responses indicated prejudgments about EV capabilities, which theoretically should not have been taken into consideration. The survey probably would have been more successful if the questionnaire had avoided reference to any particular technology. However, the NAFA data base is the only known data base that relates the physical specifications of fleet vehicles to economic utility. Moreover, the CPEN simulator, despite its need for further refinement, embodies functional relationships and independently derived coefficients that are useful for understanding how variations in vehicle characteristics affect life-cycle costs when EVs are used in fleets.

Given the potential importance of fleet activities to the introduction of new vehicular technologies, it is important to utilize the best available resources in order to understand the current needs of fleet operators. It is for this goal that this report has been generated.

*There is currently no fleet census available from which to weight the sample. 


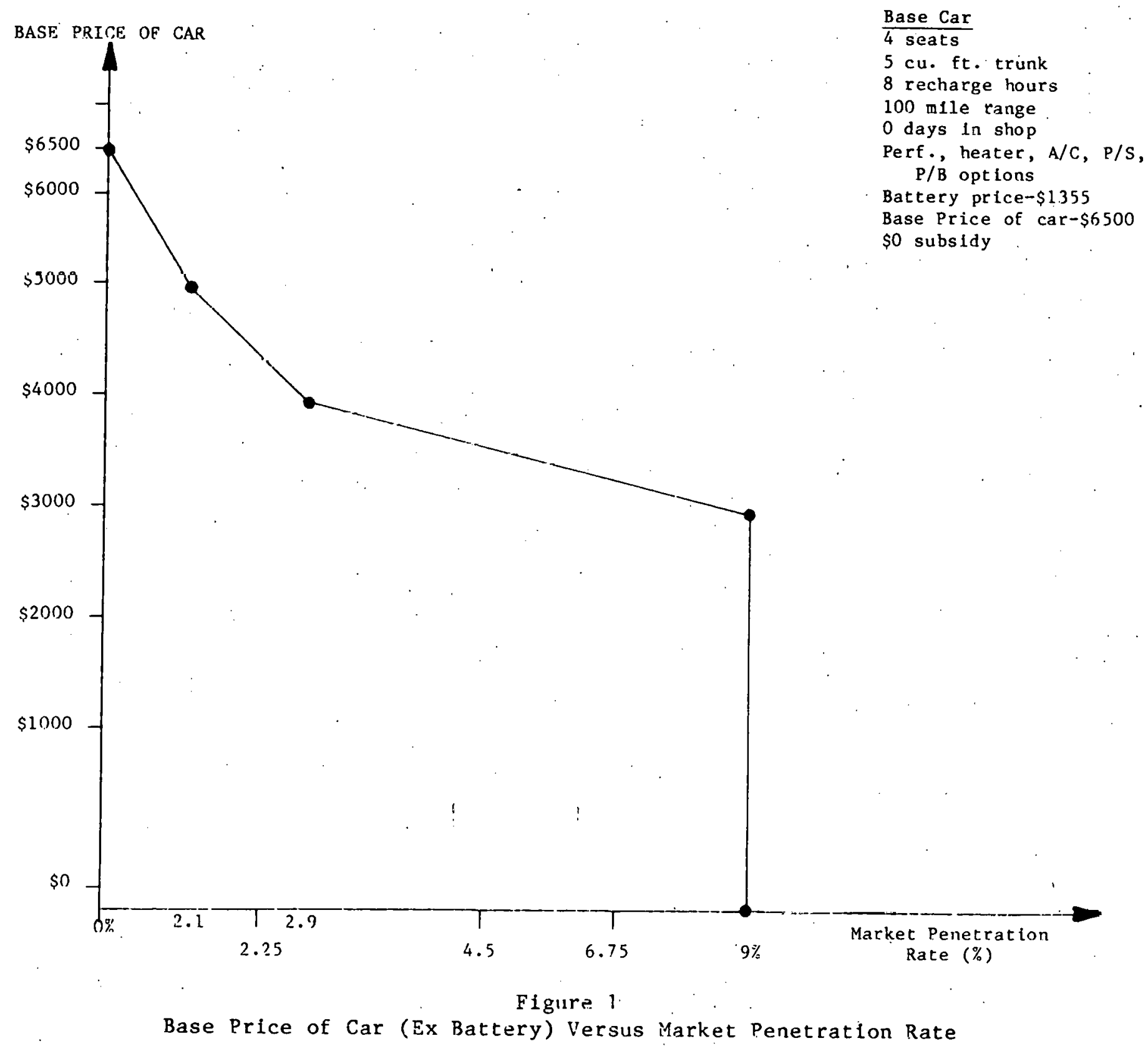




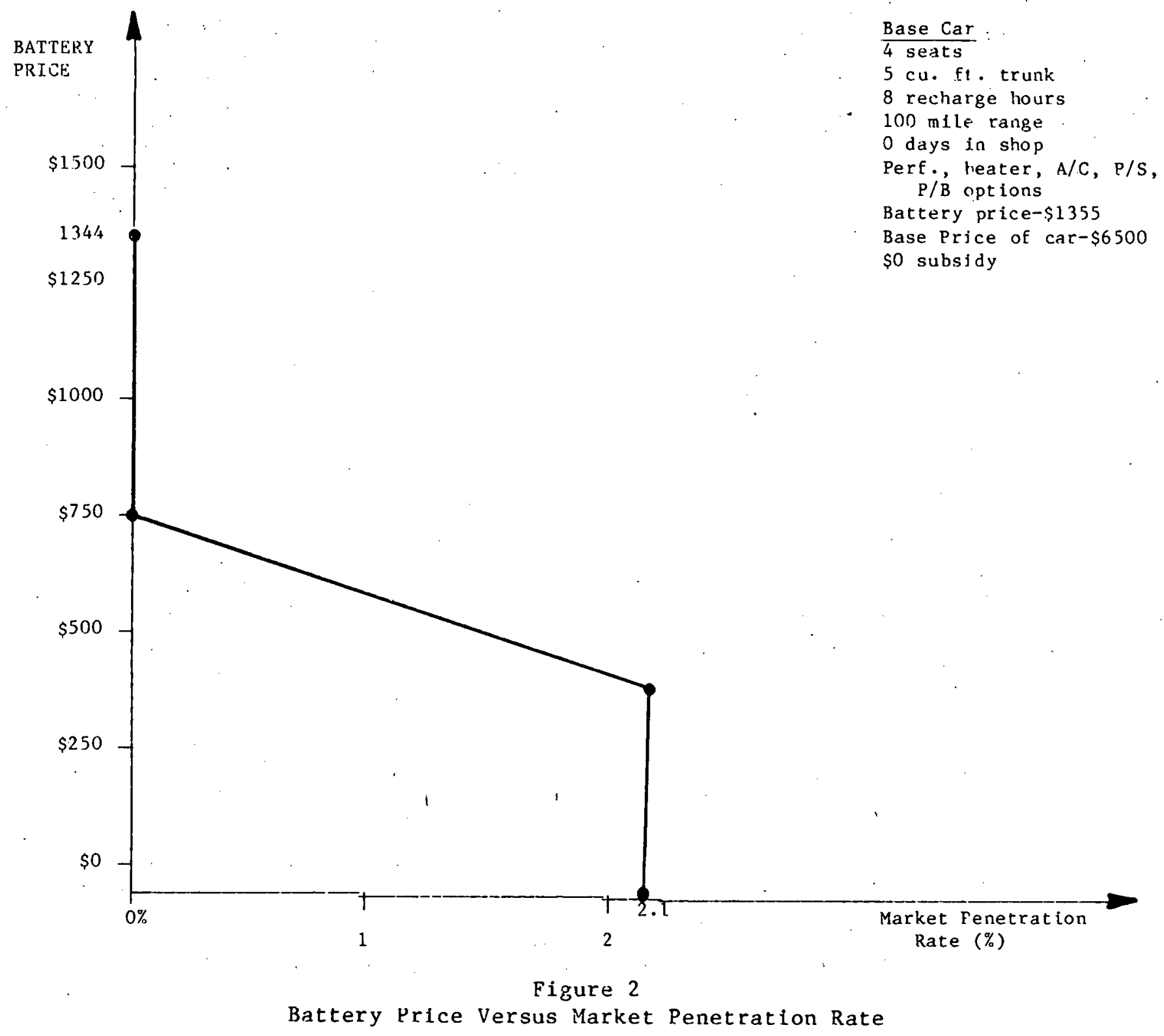




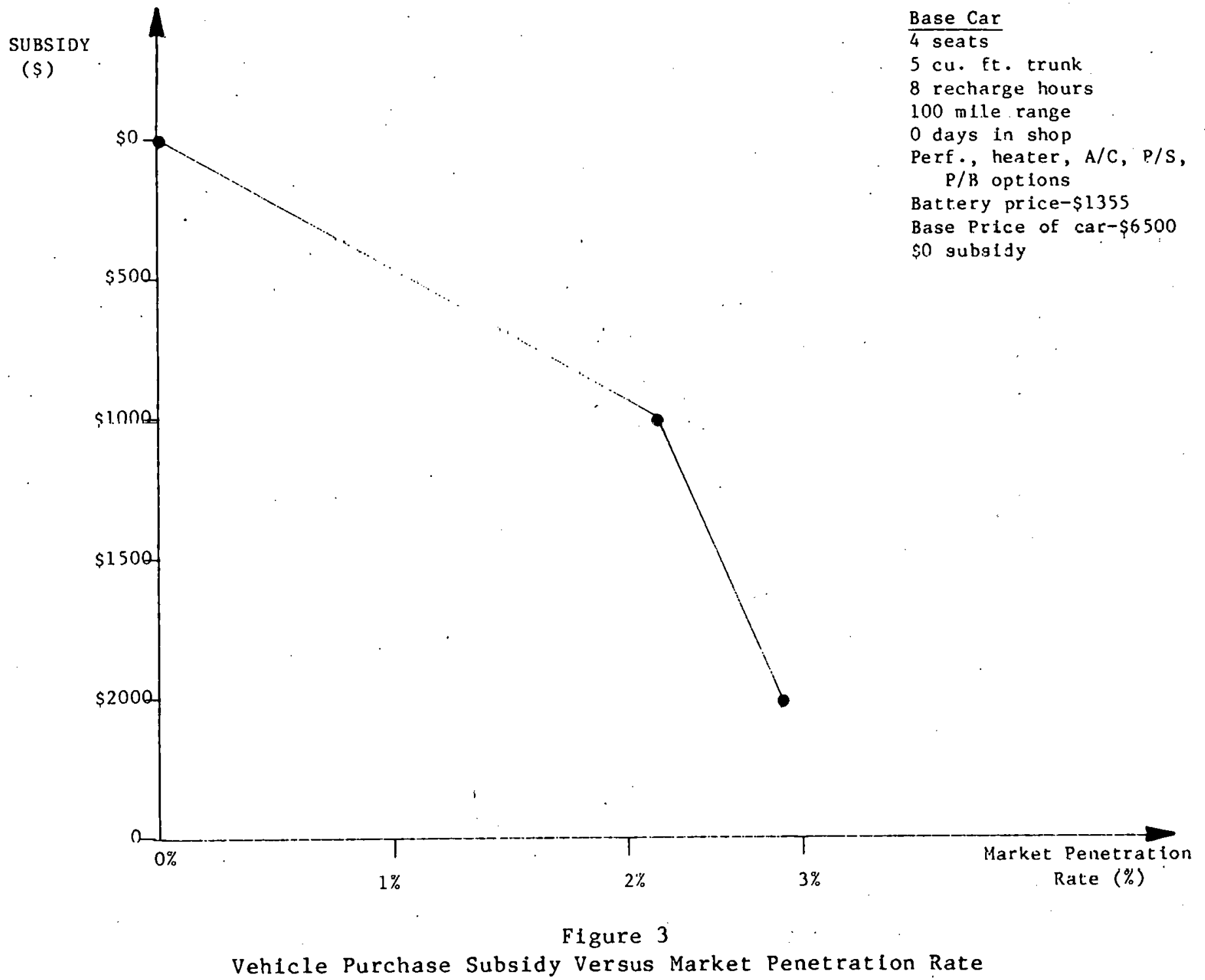




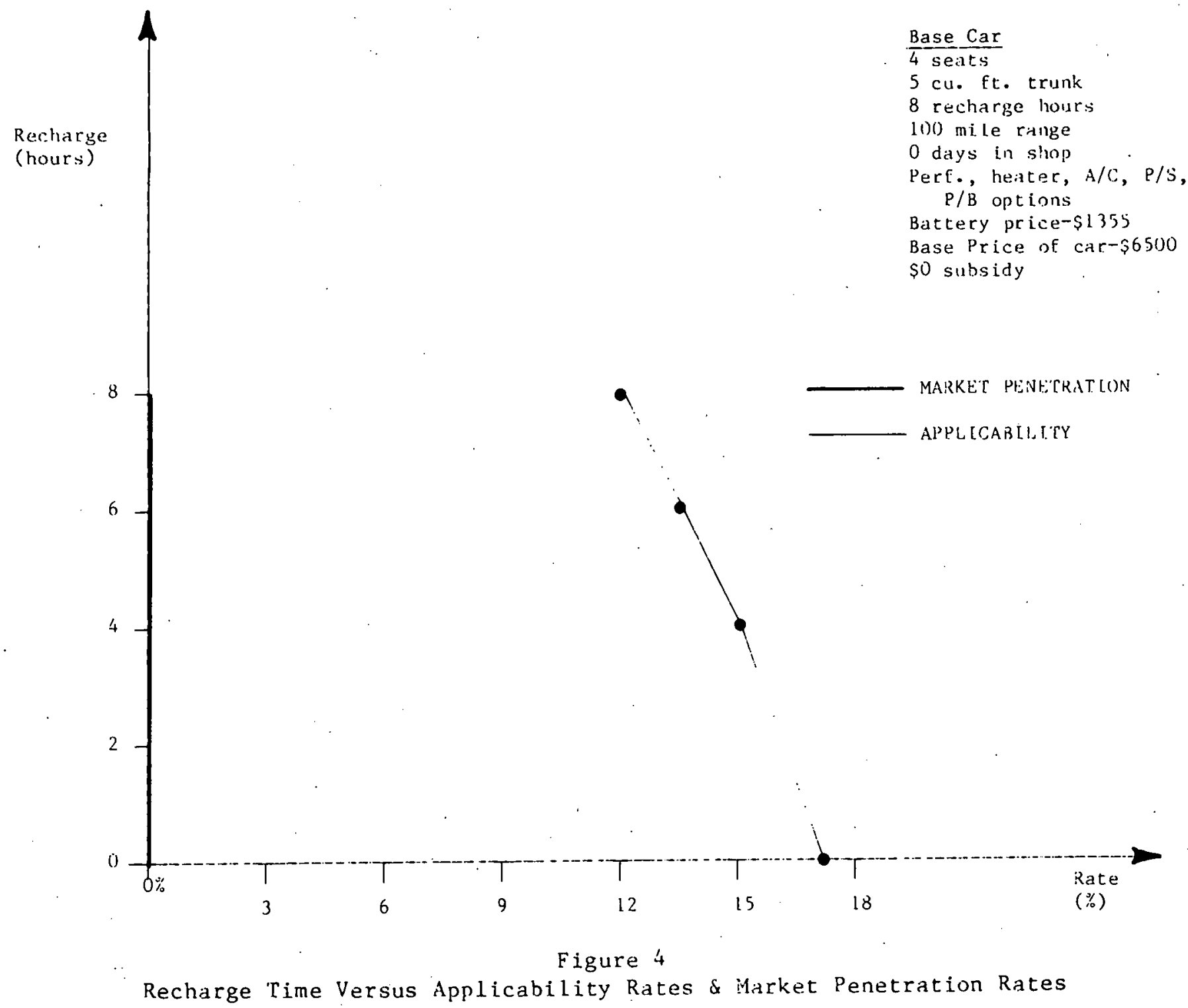




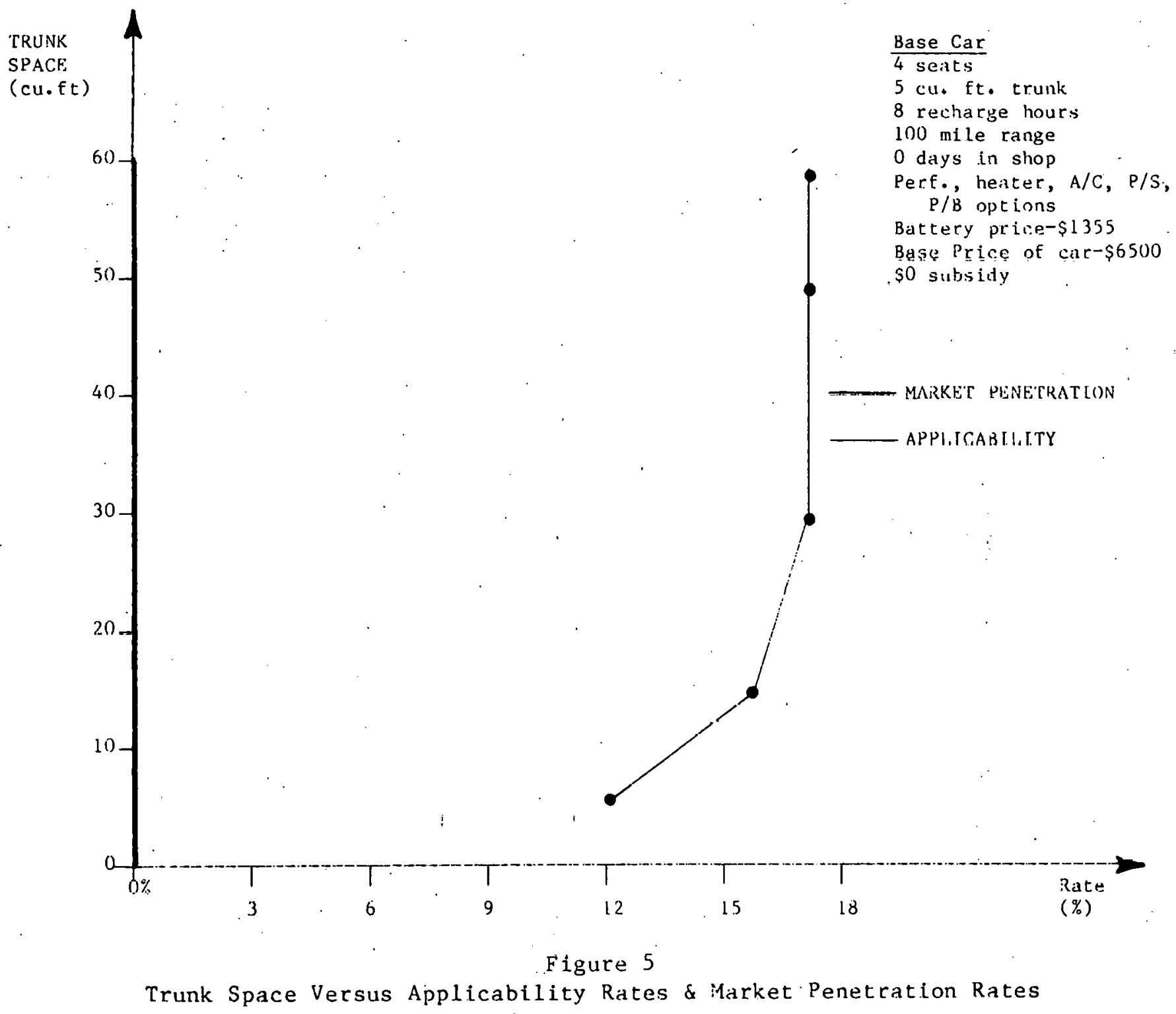




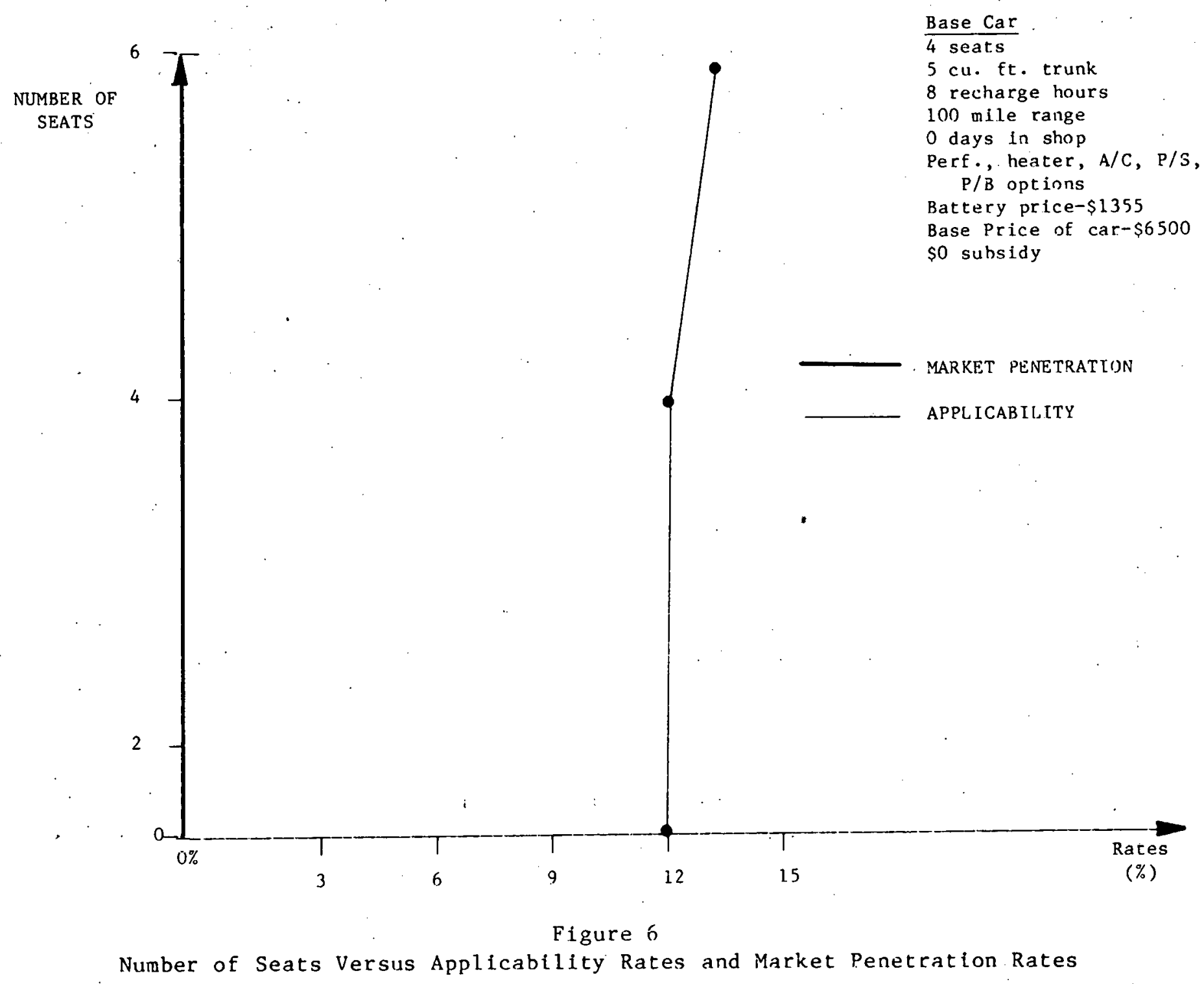




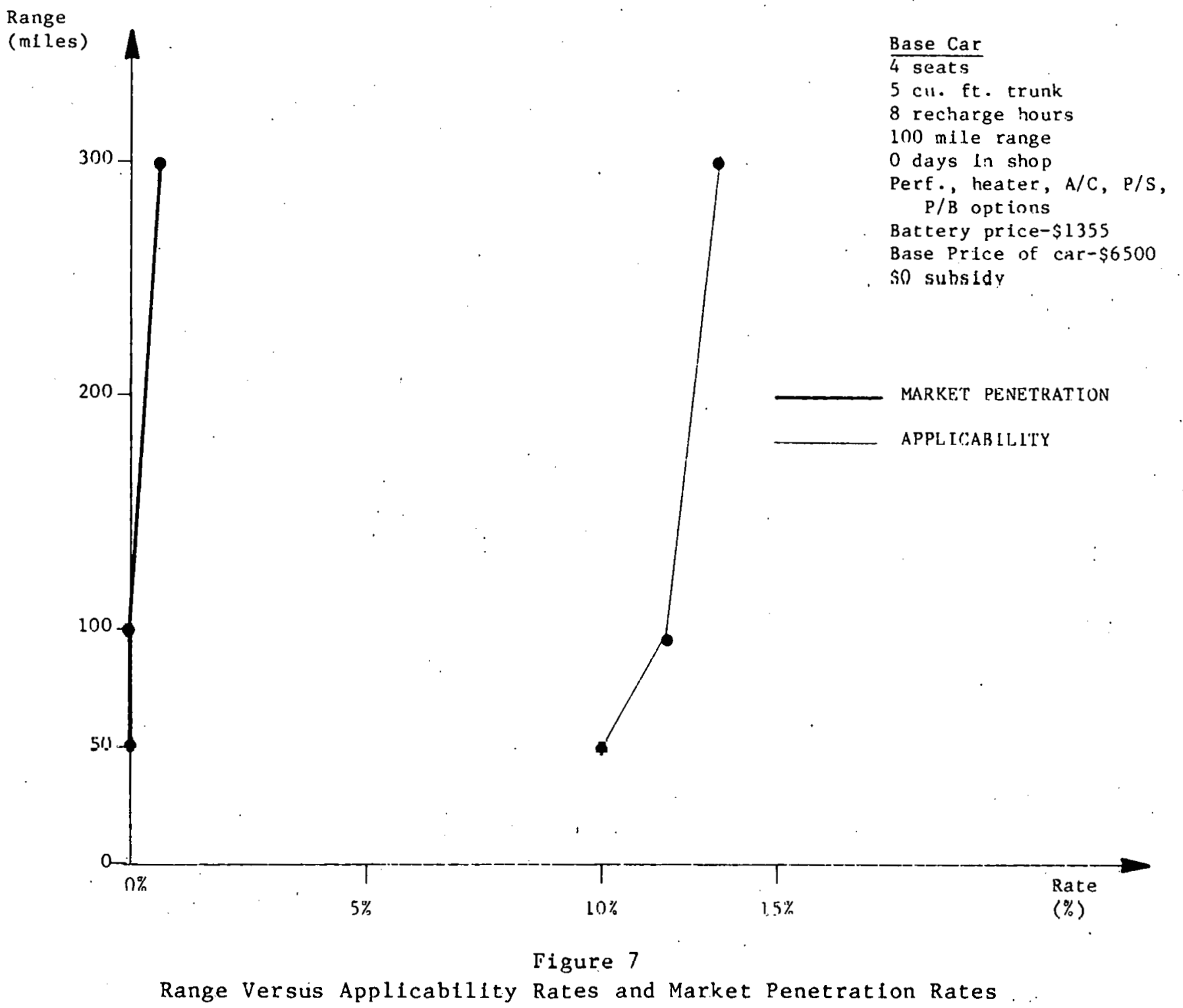


APPENDIX A 
nationatassocinton or Fleet Administrators, Qne.

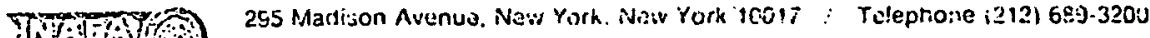

To: $\Lambda 11$ NAFA Members

From: R.L. Breault, President

Re: ELECTRIC VEHICLE SURVEY

Once popular, now scorned, will electric cars return to the American lightiv:iy?

In vicw of the ever-rising price of gasoline, the unreliablity of imported supplies, the impact of emission controls, a breat deal of rescarch is being devored to a possible rebirth of the electric car and $1 \mathrm{ghh}$ lulk 13 a potentinl vohisie of the future.

NAFA Members - a profcssional, rational car and truck buyers and Icssces ... can make an importint contribution to this research in one very specific area:

HON LARGE IS THE POTENTIAL MARKET FOR ELECTRIC VEHICLES?

The enclosed survey is designed to develop answers to that question. lic urge your cooperation in carefully studying the options offered, comparing them with your transportation needs and then completing the questionnaire.

In addition, we are taking this opportunity to gather information about NIFA members in a previously unknown area - where your cars and light trucks are located. The first sheet of the survey asks you to specify the state in which your vehicles are registered.

This information will be of great help to us in developing additional rinta alout the impact of fleets on thc toral vehjcle market, an area much overlooked by rnany resedth viganieations..

is always, your cooperation and assistance are greatly appreciated. 
NUMBER OF VEHICLES PER STATE

(If a given vehicle operaces in more than one state, assign it only to the state which serves as the vehicle's baxe of operations.)

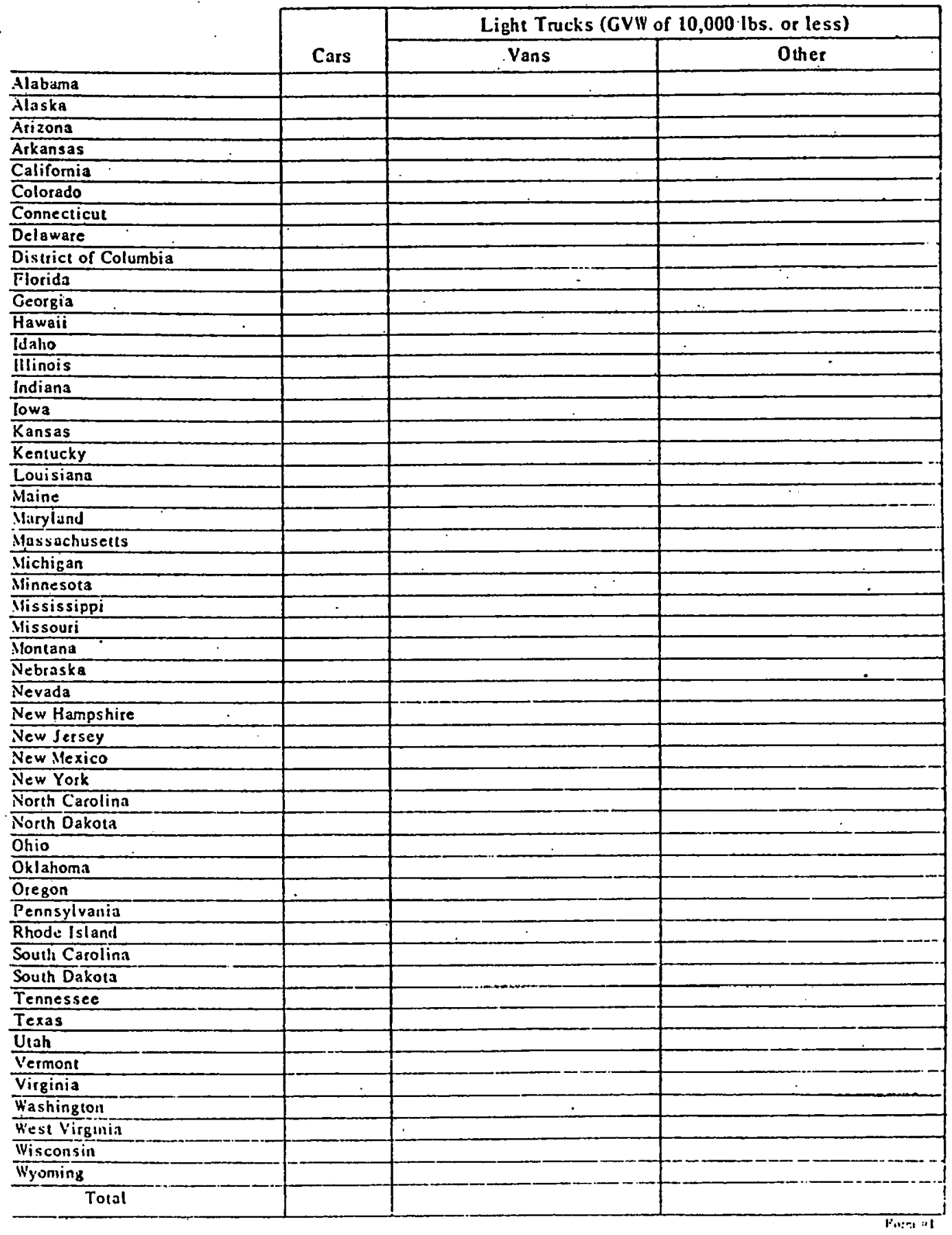




\section{NAFA@}

NATIONAL ASSOCIATION OF FLEET ADMINISTRATORS, INC.

295 Madison Avenue, New York, NX 10017

Name

Title

Company

\section{ELECTRIC CAR SURVEY}

Supposs that you must replace your cars and that the only replacements you en obtain are electric cars. The basic electric car available to you has a delivered price of $\$ 6000$. Options are available to increase the capabilities of this vehicle. All of the cars ordered do noi have to have the same options. In fact, you may order as many as three different types of optional vehicles. In the table below please specify the type(s) of optional car(s) you would order and the price you would be willing to pay for each option. Aside trom the optional character istics shown in the table, assume that the electric car is identical to the average cat you now operate. In the event that you prefer to lease vehieles; fill out the form with purchase price data and assime that your lease payments would reflect selling prices in the same manner as at present.

\begin{tabular}{|c|c|c|c|c|c|}
\hline & & $\begin{array}{l}\text { Base } \\
\text { Car }\end{array}$ & $\begin{array}{l}\text { Optional } \\
\text { Car \#1 }\end{array}$ & $\begin{array}{l}\text { Optional } \\
\text { Car \#2 }\end{array}$ & $\begin{array}{l}\text { Optional } \\
\text { Car \#3 }\end{array}$ \\
\hline 1. & $\begin{array}{l}\text { Seating Option: } \\
\text { Seating capacity de- } \\
\text { sired (fill in number, } \\
\text { including driver) }\end{array}$ & \multirow{2}{*}{ 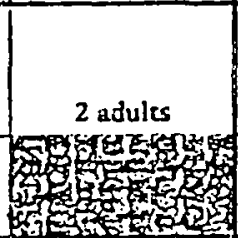 } & '_unuls & adults & _adults. \\
\hline & $\begin{array}{l}\text { Maximum price you } \\
\text { would be willing to pay } \\
\text { for this option. }\end{array}$ & & $s$ & $\$$ & $\$$ \\
\hline \multirow[t]{2}{*}{3} & $\begin{array}{l}\text { Trunk Optioni } \\
\text { Trunk space desired }\end{array}$ & \multirow{2}{*}{ 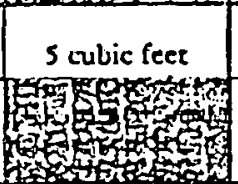 } & $\begin{array}{c}\text { muhir } \\
\text { feet }\end{array}$ & $\begin{array}{l}\text { cubic } \\
\text { feet }\end{array}$ & $\begin{array}{c}\text { cubis } \\
\text { feer } \\
\end{array}$ \\
\hline & $\begin{array}{l}\text { Maximum price you } \\
\text { would be willing to pay } \\
\text { for this option. }\end{array}$ & & 5 & 3 & 5 \\
\hline \multirow[t]{2}{*}{3.} & $\begin{array}{l}\text { Performance Option: } \\
\text { Speed \& zcceleration } \\
\text { sufficient to use } \\
\text { limited-access roads } \\
\text { (i.e., interstatcs, ex- } \\
\text { pressways) } \\
\text { (Yes or No) }\end{array}$ & \multirow{2}{*}{ No } & $\begin{array}{l}\square \text { Yes } \\
\square \mathrm{No}\end{array}$ & $\begin{array}{l}\text { DYey } \\
\text { DNo }\end{array}$ & $\begin{array}{l}\text { 口Yes } \\
\text { QNo }\end{array}$ \\
\hline & $\begin{array}{l}\text { Maximum price you } \\
\text { would be willing to pay } \\
\text { for this option. }\end{array}$ & & $s$ & $\$$ & $\$$ \\
\hline
\end{tabular}




\begin{tabular}{|c|c|c|c|c|c|}
\hline & . & $\begin{array}{l}\text { Base } \\
\text { Car }\end{array}$ & $\begin{array}{l}\text { Optional } \\
\text { Car \#1 }\end{array}$ & $\begin{array}{l}\text { Optional } \\
\text { Car \#2 }\end{array}$ & $\begin{array}{c}\text { Optional } \\
\text { Cat \#3: }\end{array}$ \\
\hline \multirow[t]{2}{*}{4.} & $\begin{array}{l}\text { Fast Recharge Option: } \\
\text { Time needed to } \\
\text { "refuel" }\end{array}$ & \multirow{2}{*}{$\begin{array}{c}8 \text { hours } \\
1\end{array}$} & _._hours & __ hours & __ hours \\
\hline & $\begin{array}{l}\text { Maximum price you } \\
\text { would be willing to pay } \\
\text { for this option. }\end{array}$ & & $\$$ & $\$$ & $\$$ \\
\hline \multirow[t]{2}{*}{5.} & $\begin{array}{l}\text { Range Option: } \\
\text { Range desired be- } \\
\text { tween "refuelings" }\end{array}$ & \multirow{2}{*}{$\begin{array}{c}30 \text { miles } \\
250 \\
250\end{array}$} & miles & __ miles & _miles \\
\hline & $\begin{array}{l}\text { Maximum price you } \\
\text { would be willing to pay } \\
\text { for this option. }\end{array}$ & & $\$$ & $\$$ & $\mathbf{s}$ \\
\hline 6. & $\begin{array}{l}\text { Pessenger Compart- } \\
\text { ment Heater: } \\
\text { (Yes or No) }\end{array}$ & No & $\begin{array}{l}\square \text { Yes } \\
\square \text { No }\end{array}$ & $\begin{array}{l}\square \text { Yes } \\
\square \text { No }\end{array}$ & $\begin{array}{l}\square \text { Yes } \\
\square \text { No }\end{array}$ \\
\hline & $\begin{array}{l}\text { Maximum price you } \\
\text { would be willing to pay } \\
\text { for this option. }\end{array}$ & For & $\$$ & $\$$ & $\$$ \\
\hline & $\begin{array}{l}\text { Air Conditioning: } \\
\text { (Yes or No) }\end{array}$ & No & $\begin{array}{l}\square \text { Yes } \\
\square \text { No }\end{array}$ & $\begin{array}{l}\text { 口Yes } \\
\square \text { No }\end{array}$ & $\begin{array}{l}\square \text { Yes } \\
\square \text { No }\end{array}$ \\
\hline & $\begin{array}{l}\text { Maximum price you } \\
\text { would be willing to pay } \\
\text { for this option. }\end{array}$ & 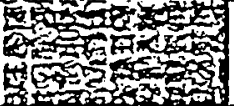 & $s$ & $\$$ & $\$$ \\
\hline & $\begin{array}{c}\text { Power Steering: } \\
\text { (Yes or No) }\end{array}$ & No & $\begin{array}{l}\square \text { Yes } \\
\square \text { No }\end{array}$ & $\begin{array}{l}\text { YYes } \\
0: 10\end{array}$ & $\begin{array}{l}\text { DYes } \\
\square \text { No }\end{array}$ \\
\hline & $\begin{array}{l}\text { Maximum price you } \\
\text { would be willing to pay } \\
\text { for this option. }\end{array}$ & 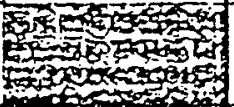 & $\mathbf{s}$ & $s$ & $\$$ \\
\hline & $\begin{array}{l}\text { Power Brakes: } \\
\text { (Yes or No) }\end{array}$ & 100 & $\begin{array}{l}\text { DYes } \\
\text { D No }\end{array}$ & $\begin{array}{l}\text { Yes } \\
\square \text { No }\end{array}$ & $\begin{array}{l}\text { QYes } \\
\square \text { No }\end{array}$ \\
\hline & $\begin{array}{l}\text { Maximum price you } \\
\text { would be willing to pay } \\
\text { for this option. }\end{array}$ & tont & $\$$ & $\$$ & $\$$ \\
\hline \multirow[t]{2}{*}{10.} & $\begin{array}{l}\text { Reliability Option: } \\
\text { Allowable annual } \\
\text { number of unsched- } \\
\text { uled days in shop }\end{array}$ & \multirow{2}{*}{ 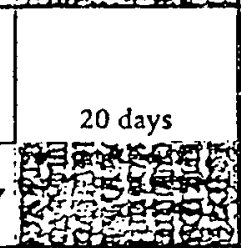 } & days & days & _days \\
\hline & $\begin{array}{l}\text { Maximum price you } \\
\text { would be willing to pay } \\
\text { for this option. }\end{array}$ & & $s$ & $\mathbf{s}$ & $\mathbf{s}$ \\
\hline \multicolumn{2}{|c|}{$\begin{array}{l}\text { II. What percentage of } \\
\text { your car fleet would } \\
\text { use each zype of car? } \\
\text { (Total of this line } \\
\text { must equal } 100 \% \text { ) }\end{array}$} & ـ & — $\%$ & — $\%$ & - $\%$ \\
\hline
\end{tabular}




\section{MAFA(O)}

NATIONAL ASSOCIATION OF FLEET AQMMINISTRATORS, INC.

295 Madison Ávanue, New York, NY 10017

Name

Title

Company

\section{ELECTRIC TRUCK SURVEY}

Suppose that you must replace your light trucks (r.VW of in,non lhs. or less) and that the only replacements you can obtain are electric trucks. The hasic electric truck available to you has a delivered price of $\$ 6000$. Options are available to increase the capabilities of this vehicle. All of the trucks ordered do nor have to have the same options. In fact, you may order as many as three different types of optional vehicles In the table below please specify the type(s) of optional truck(s) you would order and the price you would be willing to pay for each option. Aside from the optional characteristics shown in the table, assume that the electric truck is identical to the average truck you now operate. In the event that you pre fer to lease vehicles, fill out the form with purchase price data and assume that your lease payments would reflect selling.prices in the same manner as at present.

\begin{tabular}{|c|c|c|c|c|c|}
\hline & i & $\begin{array}{l}\text { Base } \\
\text { Truck }\end{array}$ & $\begin{array}{l}\text { Optional } \\
\text { Truck \#1 }\end{array}$ & $\begin{array}{l}\text { Opcional } \\
\text { Truck \#2 }\end{array}$ & $\begin{array}{l}\text { Cprional } \\
\text { Truck \#3 }\end{array}$ \\
\hline \multirow[t]{2}{*}{ i. } & $\begin{array}{l}\text { Serting Option: } \\
\text { Seating capacity desired } \\
\text { (fill in number, including } \\
\text { driver) }\end{array}$ & 2 adul & _ariults & _._._zdults & ..........adults \\
\hline & $\begin{array}{l}\text { Moximum price you would be } \\
\text { willing to pay for this option. }\end{array}$ & 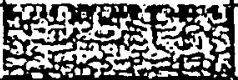 & 5 & 5 & s \\
\hline \multirow[t]{2}{*}{ ?. } & $\begin{array}{l}\text { Cango Space Option: } \\
\text { Desired full-enclosed cargo } \\
\text { space capacity }\end{array}$ & $S$ cubic feet & $\begin{array}{l}\text { cubic } \\
\text { feet }\end{array}$ & $\begin{array}{c}\text { cubic } \\
\text { feet }\end{array}$ & $\begin{array}{c}\text { cubic } \\
\text { feet }\end{array}$ \\
\hline & $\begin{array}{l}\text { Maximum price you would be } \\
\text { willing to pay for this option. }\end{array}$ & (1) & $\$$ & $\$$ & $\$$ \\
\hline \multirow[t]{2}{*}{3.} & $\begin{array}{l}\text { Payloail Option: } \\
\text { Desired cargo weight } \\
\text { capacity (including driver } \\
\text { \& passengers) }\end{array}$ & 500 Lbs. & __Lbs. & Lbs. & Lbs. \\
\hline & $\begin{array}{l}\text { Maximum price you would be } \\
\text { willing to pay for this option. }\end{array}$ & xitas & $\$$ & 3 & 5 \\
\hline
\end{tabular}




\begin{tabular}{|c|c|c|c|c|c|}
\hline & & $\begin{array}{l}\text { Base } \\
\text { Truck }\end{array}$ & $\begin{array}{l}\text { Optional } \\
\text { Truck \#1 }\end{array}$ & $\begin{array}{l}\text { Optional } \\
\text { Truck \#2 }\end{array}$ & $\begin{array}{l}\text { Optional } \\
\text { Truck \#3 }\end{array}$ \\
\hline & $\begin{array}{l}\text { Performance Option: } \\
\text { Speed and acceleration suf- } \\
\text { ficient to use limited-access } \\
\text { roads (i.e., interstates, } \\
\text { expressways) } \\
\text { (Yes or No) }\end{array}$ & No & $\begin{array}{l}\square \text { Yes } \\
\square \text { No }\end{array}$ & $\begin{array}{l}\text { QYes } \\
\square \text { No }\end{array}$ & $\begin{array}{l}\square \text { Yes } \\
\square \text { No }\end{array}$ \\
\hline & $\begin{array}{l}\text { Maximum price you would be } \\
\text { willing to pay for this option. }\end{array}$ & 1950 & $\$$ & $\$$ & $s$ \\
\hline \multirow[t]{2}{*}{5.} & $\begin{array}{l}\text { Fast Recharge Option: } \\
\text { Time needed to "refuel" }\end{array}$ & 8 hours & _ hours & __ hours & _._hours \\
\hline & $\begin{array}{l}\text { Maximum price you would be } \\
\text { willing to pay for this option. }\end{array}$ & 105is & $\$$ & $\$$ & $\mathbf{s}$ \\
\hline 6. & $\begin{array}{l}\text { Range Option: } \\
\text { Range desired between } \\
\text { "refuelings" }\end{array}$ & 30 miles & _miles & _miles & _miles \\
\hline & $\begin{array}{l}\text { Maximum price you would be } \\
\text { willing to pay for this option. }\end{array}$ & 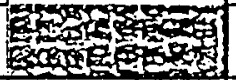 & $\$$ & $\$$ & $\$$ \\
\hline 7. & $\begin{array}{l}\text { Passenger Compartment } \\
\text { Heater: } \\
\text { (Yes or No) }\end{array}$ & No & $\begin{array}{l}\square \text { Yes } \\
\square \text { No }\end{array}$ & $\begin{array}{l}\square \text { Yes } \\
\square \text { No }\end{array}$ & $\begin{array}{l}\square \text { Yes } \\
\square \text { No }\end{array}$ \\
\hline & $\begin{array}{l}\text { Maximum price you would be } \\
\text { willing to pay for this option. }\end{array}$ & trets & $\$$ & $s$ & $\mathbf{s}$ \\
\hline \multirow[t]{2}{*}{8.} & $\begin{array}{l}\text { Air Conditioning: } \\
\text { (Yes or No) }\end{array}$ & No & $\begin{array}{l}\text { 口Yes } \\
\square \text { No }\end{array}$ & $\begin{array}{l}\text { DYes } \\
\square \text { No }\end{array}$ & $\begin{array}{l}\text { DYes } \\
\text { DNo }\end{array}$ \\
\hline & $\begin{array}{l}\text { Maximum price you would be } \\
\text { willing to pay for this option. }\end{array}$ & 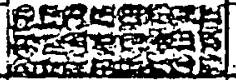 & $\$$ & $\$$ & $s$ \\
\hline & $\begin{array}{l}\text { Power Steering: } \\
\text { (Yes or No) }\end{array}$ & No & $\begin{array}{l}\text { DYes } \\
\square \text { No }\end{array}$ & $\begin{array}{l}\text { IYes } \\
\text { प No }\end{array}$ & $\begin{array}{l}\square \text { Yes } \\
\square \text { No }\end{array}$ \\
\hline & $\begin{array}{l}\text { Maximum price you would be } \\
\text { willing to pay for this option. }\end{array}$ & (2) & $\$$ & $\mathbf{s}$ & $\$$ \\
\hline \multirow[t]{2}{*}{10} & $\begin{array}{l}\text { Power Brakes } \\
\text { (Yes or No) }\end{array}$ & No & $\begin{array}{l}\square \text { Yes } \\
\square \text { No }\end{array}$ & $\begin{array}{l}\text { DYes } \\
\text { aNo }\end{array}$ & $\begin{array}{l}\text { DYes } \\
\square \text { No. }\end{array}$ \\
\hline & $\begin{array}{l}\text { Maximum price you would be } \\
\text { willing to pay for this option. }\end{array}$ & 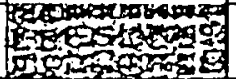 & $s$ & $\mathbf{s}$ & $\mathbf{s}$ \\
\hline 11. & $\begin{array}{l}\text { Reliability Option: } \\
\text { Allowable annual number of } \\
\text { unscheduled days in shop }\end{array}$ & 20 days & days & $\therefore$ days & _days \\
\hline & $\begin{array}{l}\text { Maximum price you would be } \\
\text { willing to pay for this option. }\end{array}$ & 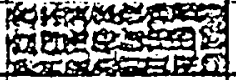 & $s$ & $s$ & $s$ \\
\hline 12. & $\begin{array}{l}\text { What percentage of your truck } \\
\text { fleet would use each type of } \\
\text { tuck? } \\
\text { (Total of this line must equal } \\
100 \% \text { ) }\end{array}$ & ${ }^{2}$ & - $\%$ & $\%$ & - $\%$ \\
\hline
\end{tabular}

